\title{
DE OORZAKEN VAN DEN OPSTAND VAN SAPAROEA IN 1817.
}

DOOR

\author{
$M^{R}$. H. A. IDEMA.
}

\section{Inleiding.}

Bij het in het licht geven van de hieronder volgende bijdrage - de vrucht van een plaatselijk archief-onderzoek - ga vooraf een woord van dankbare erkenning en van groote waardeering voor hetgeen de grijze navorscher der politieke geschiedenis van ons Indië in het begin van de $\mathrm{XIX}^{\mathrm{e}}$ eeuw, wijlen $\mathrm{P}$. H. van der Kemp, heeft bijeengebracht en gecommentarieerd. Men neme de nieuwste literatuurlijst over het tijdvak van het Herstel van ons gezag en schrappe daarin den naam van Van der Kemp, houdt men dan wel veel meer over dan verspreide nota's, diverse memoires en wat krijgsgeschiedenis? «Wat daarvan als publicatie gegeven was" - schreef Van der Kemp - "bestond zonder samenhang en mocht in velerlei opzicht diep treurig heeten»; uit dien hoofde gaf hij er zich geheel aan, zich het eerst zettende aan bijzondere onderwerpen, doch steeds rijper werd de vrucht van zijn studie, al vollediger de verzameling der soms van heinde en verre aangevoerde gegevens; ten taak stelde hij zich ten slotte - gelijk hij neerlegde in het eerste deel van zijn Nijhoffwerken in 1913 - een arbeid te verrichten over dat historisch tijdvak, "die zich van den aanvang af heeft ten doel gesteld steeds opnieuw archiefonderzoek over hetzelfde onderwerp onnoodig te maken en een bron van kennis te openen niet slechts voor de staatkundige, doch ook voor de administratieve ontwikkeling van ons Indië na zijn herstel». "Mijn artikelen» — zeide hij elders, toen hij zijn bezorgdheid uitte over het verschijnen der Instituutsbijdragen met de op de nieuwe auteurswet steunende waarschuwing: "Overneming verboden", "mijn artikelen stel ik samen met de gedachte dat zij zoo degelijk zijn bewerkt, dat, wanneer men hetzelfde onderwerp daarna 
behandelt, men er niet buiten kan om, onder welken vorm dan ook, er iets van over te nemen.,

Ontveinsd heeft Van der Kemp zich nochtans niet dat «time is continually adding Postcripts to their Finis», en wanneer in 1919 hem een ontboezeming ontsnapt over »de onveranderlijkheid der verschijnselen in de theoretische wetenschap vergeleken met die, welke beoefent het verband der verschijnselen die ons enkel uit het verleden geopenbaard kunnen worden», dan vraagt hij ten slotte zich zelfs af, "of van de geraadpleegde bronnen wel de waarheid uitgaat, en of zij de laatsten zijn die wij mogen hopen te verkrijgen». Hoe gaarne had ik dan ook dien onvermoeiden navorscher zelf willen toonen wat wij op Ambon gevonden hebben met betrekking tot hetzelfde tijdvak, waaraan Van der Kemp zich had gewijd!

Mijne plaatsing te Ambon riep al ras de herinnering in mij op aan Van der Kemp's breede studie over het Herstel van het Nederlandsch Gezag in de Molukken in 1817, verschenen in deel 65 dezer Bijdragen, gevolgd in 1913 door zijn Nadere mededeelingen en in deel 75 door het artikel: Over den Opstand in de Molukken. Als altijd gaf ook hier Van der Kemp personen en toestanden weder, zooals omvangrijke lectuur en onverdroten archiefstudie deze aan hem hadden geopenbaard: hem moest daarbij uit de pen, hoezeer hij onze Commissarissen voor de overneming der Molukken, Engelhard en Van Middelkoop, zag als "prullen van menschen,, wier eigenwaan en gemis aan waardigheidsbesef aanleiding hebben gegeven tot jammerlijke ruziën, en dit, waar het gewestelijk gezag voor de zware taak stond om het landsbestuur naar den eisch van den nieuwen tijd in handen te nemen. Met groote toewijding zette Van der Kemp er zich toe ook in dit geval de geschiedenis opnieuw te hanteeren, niet alleen om daarvan een volledig relaas te geven, maar ook viel daarbij iets goed te maken tegenover de nagedachtenis der mannen, die hun leven of hun gezondheid ten offer gebracht hadden aan dien in moord uitgebroken en welhaast in krijgsgeweld en terechtstelling geëindigden opstand van Thomas Matulesia op Saparoea.

Onze archiefvondsten leidden in eenigszins andere richting, hoewel betrekking hebbende op hetzelfde tijdvak, gelijk trouwens het materiaal, dat de vieze archiefzolder van het Ambonsch Residentie-kantoor heeft opgeleverd, zooals het dat in manden en wagens uit ruwe koeliehand had overgenomen van het oude 
gebouw, wel wat verschilt van hetgeen een Hollandsch Archief aanbiedt, zooals dit pleegt te zijn geordend; waar de archivalia ordelijk worden bewaard, de beambte vaardig de verzochte portefeuille brengt, rapporten van aanwinsten en catalogi ten dienste staan, en eerbiedig bewaarde familiestukken ter beschikking worden gesteld. Duikt op Ambon iemand op, die vergeelde papieren wil doen spreken, dan gaat deze met 's Residents oppasser den zolder op, en heeft hij zich zelf een weg te banen in een doolhof. Maar vergeefs was het zoeken niet, al was mij bekend dat het oude archief uit den tijd van de Compagnie en verder tot de Overneming, in 1881 naar Batavia was gezonden.

Aanvankelijk was ik van plan om aan de hand van de stukken en brokken, welke ik vond ${ }^{1}$ - er zou eigenlijk nog veel meer moeten liggen dan door mij werd aangetroffen - naast de geschiedenis van den opstand van Saparoea en om de groote lijnen van het bestuursbeleid heen, door Van der Kemp zoo volledig getrokken, naar bescheiden vermogen te trachten het Ambon van dien tijd uit een sociaal-economisch oogpunt bij te teekenen. Waar Regeering en Hooge Colleges door Van der Kemp als het ware reeds ten voeten uit geschilderd waren: H.H. Commissarissen, Gouverneur, Militaire Commandant, Residenten ter hoofdplaats en op de Buitencomptoiren, Superintendenten van de Negorijen en de Scholen, - daar had ik tot verdere stoffeering gaarne nader wat willen vertellen van de mindere goden. Niet in de laatste plaats van den Magistraat onzen Djaksa - die al dadelijk in April 1817 de instructie meêkreeg "geen boeten op te leggen buiten vonnis, en het recht zijn loop te laten zonder daarover in eenige overeenkomst te treden.» Verder van den uit leeken bestaanden Raad van Justitie en van het Secretariaat van Huwelijks- en kleine gerechtszaken - een bijbaantje voor den Winkelier van de Lijnwaden. Wat door zeewater was beschadigd; moest deze met zuiver water uitwasschen en hadden, o ongeluk! de witte mieren hunnen loop genomen door een pak sarongs, dan kwamen «expresse gecommitteerdens tot een wijdloopig procesverbaal onder aanbod van eede.» Voor 's Landsinkomsten moesten zorgen: de Directeur van het Note-huijs te Banda, die van de Nagelenafpakschuur te Saparoea, de collecteur van 's Heeren Gerechtigheid, van Groot en Klein Zegel en de Pachter van Arak en Saguweer;

\footnotetext{
1 Zie hierachter, bl. 640. (Red. der Bïdragen).
} 
voor 's Lands goederen de Pakhuismeester en de zoo belangrijke Gecommitteerdens voor Onderwigten, Minderheden en Spillagie bij de In- en Uytweging, Ontvangst en Afscheep. Den dienst der B. O.W. vond men voor dien tijd gepersonifieerd in den opperbaas-ijzersmid en den baasscheepstimmerman van 's Lands Ambachtswinkel. Als vertegenwoordigende het profanum vulgus, zou men kunnen wijzen op den droevigen stoet van «supplianten en needrige teekenaars», ondergeteekenden zeggen wij, die verzoekt een oog van medelijden op hen gelieven te vestigen "met hieronder een Moeder van zooveel vaderlooze wezen», en verder oud-militairen *uit consideratie van langjarige dienst en trouwe ootmoedig rekestreerend om eenig soulagement», - een verzoek, hetwelk van tijd tot tijd mondeling wordt "gedeclineerd.» Onder de afdeeling Justitie zouden behandeling mogen vinden de publieke correcties op de bazaar; het geeselen en brandmerken op de plaats van het misdrijf alvorens voor jaren naar Ceram of Boeroe te worden verbannen, of met den strop om den hals aan de galg te worden gesteld; al de doesoen-geschillen en verzoeken om afstand van Gouvernementsgrond; scheldpartijtjes tusschen buren; al de bemoeienis met weer opgepakte slaven, waarvoor door den Lijfsheer opvatloon en detentiegelden waren verschuldigd, en met pandelingen die moesten worden geregistreerd, terwijl naar het bedrag hunner schuld hun diensttijd werd bepaald. ${ }^{1}$ Ook moesten politieke en andere bannelingen verzorgd; op Banda, waar men in de perken grootendeels met bannelingen moest werken, was het dezen atotaal onmogelijk om te gewennen doordien $\mathrm{zij}$, vrouwen ontbrekende, daarover dagelijks twisten veroorzaken; naar 's Gouverneurs gedagte zouden twee à driehonderd vrouwen als een teugel voor het slegte volk kunnen dienen, hetgeen den G.G. beleefd in overweging wordt gegeven.» Niet onder het Bestuur, maar onder Financiën zouden ressorteeren de rekeningen van nagelen, noten en foelie; men vindt een Regent in civiele bewaring gezet wegens verwaarloozing der nagelen - zooals een monster bevestigt - en een tweede ontslagen "wegens verregaand plichtsverzuim, hebbende hij de nagelen tot moernagelen laten worden.${ }^{2}$ 's Lands kas trachtte

1 Gepubliceerd in Ind. Stbl. $1822 \mathrm{n}^{\circ} 10$.

2 Vergelijk de als Bijlage hierachter opgenomen Provis: Instructie voor „Radjas, Pattijs en Orangkajen", de voorlooper van het nog geldende Reglement op Binnenl. Bestuur en Finantiën (Stbl. $1824 \mathrm{n}^{\circ} 19 \mathrm{a}$ ). 
men te vullen met 's Heeren Geregtigheid op verkochte vaste goederen, het Groot en Klein Zegel en de pacht van arak, saguweer en amfioen, het hoofdgeld der Chineezen, de tiende en twintigste penning bij versterf - al naar den graad van verwantschap - en de tolgerechtigheid - geheven ook van den Chineeschen importeur van "feine batikse neusdoeken.» 1

Het terrein van Binnenlandsch Bestuur was ook in die dagen al zeer uitgebreid: de hongitocht werd gehandhaafd als een tweejaarlijksche groote inspectiereis van den Gouverneur, waarvoor iedere negorij zijn orembayen leverde, tegen 15 October gereed aan het Hoofdkasteel te Ambon, in goeden staat, wel bemand en behoorlijk van zeil en treil voorzien. ${ }^{2}$ Van tijd tot tijd rapporteerde men van Ceram zeeroovers en sneltochten; de vivres en rantsoenen van Koloniale Marine brachten hun administratie mee (bij aanhoudende regens kreeg men een dubbel rantsoen arak). Moesten schepen worden ingehuurd dan ging dat per kojang en dan, o sancta simplicitas, werd een inlandsche soldatenvrouw op $\frac{1}{4}$ kojang, een Europeesch flankeur op $\frac{1}{2}$ berekend, een officier op een heele, een hoofdofflcier zelfs op twee kojang. De voorzieningen eerst uit de centrale Javamagazijnen, dan ter verdere distributie over de Buitenposten, was een voortdurende zorg voor de "expresse gecommitteerdens bij in- en uitweeg, ontvangst en afscheep; bij minderheden boven het bij uitvoerig tarief bepaalde moest de betrokkene de zuiveringseed presteeren adat dit direct noch indirect door zijn toedoen was veroorzaakt» en booze correspondentie ontstond over de vraag of ook een officier, die eenmaal den eed aan den Koning had gezworen, ook hiertoe was verplicht. Ja, ook vond ik een circulaire om geen papier te vermorsen ten einde "een onnoodigen aanwas van 's Gouverneurs archieven voor te komen". "Inlandse, Zaken stonden des tijds heel wat minder in de belangstelling, echter moesten de ook toen al talrijke klachten tegen Regenten geëxamineerd worden, en werd, naar bevind van zaken, den Regent bevolen seen meer politieke behandeling zijner onderhoorigen»

1 Provisioneel Reglement op In- en Uitgaande Rechten van 20 Juni 1818 de vroegere „boompacht". Vergelijk Reglement Commiss.-Generaal voor Java en Madoera 28 Aug. 18, Staatsbl. $\mathrm{n}^{\circ} 58$, idem voor zegelordonnantie 16 October 1817, Stbl. no 50. - De Encyclopaedie van Ned.-Indië, dl. I blz. 222 en vlg. sub voce Belastingen geeft voor ieder middel een breede historische inleiding.

2 Vergelijk art. 15 en vlg. van de Prov. Instructie voor de "Radjas, Pattijs en Orankajen". 
dan wel werd de lichtzinnige klager voor 3 jaar naar Boeroe gezonden.

Handel en scheepvaart werden eerst heel langzaam de teugels een weinig gevierd. Met betrekking zelfs tot het Armwezen ontbreekt de stof niet ten eenenmale: tot instandhouding eener leproserie op het eilandje Molano bij Saparoea - elders heet dat oord bestemd "voor hen, die door de Lazarusziekte zijn aangetast» - was vastgesteld een Reglement, waarbij iedere negurij tot levering van goed of geldelijke bijdrage verplicht was; en op een Inteekenlijst voor het Doofstommeninstituut te Groningen en dat voor blinden te Amsterdam, «teekende ieder ambtenaar voor het bedrag van één dag traktement.

Echter: tot een zooveel omvattende aanvullende schildering ontbrak mij de tijd: ik had mij te beperken en bepaalde mij mitsdien tot het aanbrengen op de schilderij van Van der Kemp, voor zoover de oorzaken van den opstand betreft, van wat frissche kleur, en - hetgeen mij niet onbelangrijk toeschijnt - het bijschilderen van V. d. Kemp's figuur van Van Middelkoop, dien «stommen v. M.», zooals V. d. Kemp ergens over dezen Commissaris uitvalt. Zeker, Van Middelkoop was geen man van kracht, noch begaafd met diepgaand bestuursbeleid; de overneming van de Molukken uit de handen van den vriendelijken Engelschen Gouverneur, dat ging goed, maar met naast zich den "leuterenden" mede-Commissaris Engelhard, was Van Middelkoop geenszins tegen een opstand opgewassen. Intusschen denke men zich ook eens wat dieper in de toenmalige omstandigheden op Ambon in: zonder geld en "zonder zwitsers*, alleen met papier en pen benevens veel goeden wil zouden onze Commissarissen van het slordig Engelsch beheerd gouvernement een model-Hollandsche kolonie maken. Toen bij de herstelling van ons gezag het nieuwe bestuur het régime dan ook vrij wel langs de oude lijnen liet loopen, kwam het op het altijd roerig Saparoea al dadelijk tot een botsing, zóó dat de vlam er uit sloeg, - en alstoen was voorzeker geen van onze beide Commissarissen hier op zijn plaats.

$\mathrm{Bij}$ het navolgende komt het nuttig voor eenige data op den voorgrond te stellen: bij zooveel belangrijks in zoodanig kort tijdsbestek als bij dezen opstand van Saparoea heeft plaats gevonden, dragen dgl. data krachtig bij om de feiten duidelijk te doen spreken: Dl. 79. 
8 Maart 1817: aankomst der Commissarissen.

14 Mei: begin van den opstand op Saparoea.

20 Mei: expeditie onder Majoor Beetjes in de pan gehakt.

1 October: aankomst van Buijskes.

16 November: plechtige dankdienst te Saparoea; einde van het verzet. ${ }^{1}$

\section{Oorzaken van den opstand.}

V. d. Kemp noemt, aan de hand van Van Middelkoop's beide verdedigingsmemories, acht oorzaken ${ }^{2}$ :

1. het papiergeld;

2. de order tot het maken van zout;

3. de aanleg van een notenplantage;

4. de houtaankap en levering van atap en gaba-gaba;

5. de afdanking van schoolmeesters en de verplichting om de kinderen van Saparoea vooral ter hoofdplaats te doen schoolgaan;

6. de aanwerving van Amboneezen voor militairen dienst te Batavia ;

7. de levering van droge visch en dengdeng; en

8. de gedwongen levering van koffie.

Welke van alle deze oorzaken, zoo simpel opgesomd, heeft het volk het meest gegriefd?

Laten we eens hooren wat de opstandelingen zelf er van zeggen:

Er bestaan n.l. twee cahiers de doléances: ten eerste de veertien punten, waarop de leider van den opstand Thomas Matulessy handteekeningen van de Regenten van Saparoea en Noesa Laoet verzamelde $-29 \mathrm{Mei}^{3}$ - en in de tweede plaats het Verslag

1 Bij het aanhalen van V. d. Kemp noem ik slechts het jaartal van verschijning zijner studie:

v. d. Kemp 1911 wijst dus naar zijn: Herstel Nederlandsch gezag Molukken 1817 (Bijdragen dl. 65-66).

V. d. Kemp 1913 naar zijn Nederl. Ind. Bestuur 1817 tot vertrek Engelschen ('s-Hage, M. Nijhoff).

V. d. Kemp 1915 naar zijn Nederl. Ind. Bestuur midden 1817. (Nijhoff).

V. d. Kemp 1917 naar zijn Nederl. Ind. Bestuur 1817/1818. (Nijhoff).

V. d. Kemp 1919 naar zijn Ontslagen Gouv.: v. Middelkoop en Schout bij Nacht Buijskes over opstand Molukken (Bijdragen dl. 75).

2 V. d. K. 1919 bl. : 156.

s V. d. K. 1915 bl. 29. 
der onderhandelingen van de Luitenants Ellinghuijzen en Christiaansen te Hatawono van 13 Juli. ${ }^{1}$ Voor beider betrouwbaarheid pleit, dat het eerste stuk is opgesteld dadelijk na het succes op Majoor Beetjes, het laatste toen de tweede expeditie ook strotsch en uitdagend werd afgewacht».

Al deze klachten dan meen ik te mogen terugbrengen tot twee groepen, n.l.:

$1^{\circ}$. die van economischen en

$2^{\circ}$. andere van volkpsychologischen aard.

Tot de eerste reken ik den houtaankap en allerlei leveranties van atap, gaba gaba, droge visch, dengdeng, koffie, ja wat al niet, nog verzwaard door de proeven met zoutaanmaak en de notencultuur.

Onder de tweede groep vallen dan de kwesties van kerk en school en de werving.

\section{De aankap van hout en andere leveringen.}

Matulessy zegt: "Wij hebben veel zwaar werk gedaan voor het gouvernement, maar geen loon ontvangen. Van de Engelsche Regeering kregen we steeds betaling. De Resident heeft gelast dat wij zout zouden maken, dat wij droge visch moesten leveren. Vol hebben wij onze handen met nagel- en koffietuinen, toch is ons nog gelast notenmuskaattuinen aan te leggen.» Bij de komst der tweede expeditie klaagde het volk adat zij hout en zout, gedroogd vleesch en visch zonder betaling moesten leveren. Dat alle werken en leveranties van materialen, die vroeger door de Nederlanders en Engelschen betaald werden, thans kosteloos werden verlangd.

Bekend is, dat het hout ${ }^{2}$ op Saparoea als "lont in het buskruit heeft gediend»; een lading nanyhout ${ }^{3}$ - een houtsoort buitengewoon bestand tegen paalworm, aanbevolen in zeewater, echter uiterst moeilijk te bewerken - bestemd voor 's Lands werf te Amboina werd nl. uit de prauw gesleept, die klaar lag voor vertrek. Daarvoor gold volgens V. Middelkoop een billijk loon, maar slechts "als kap- en sleeploon, daar het hout niet het hunne, maar als op Gouvernementsgrond in het wild voort-

1 v. d. K. 1911 bl. 670 .

2 V. d. K. 1915 , bl. 58.

s Niet "nanni"hout zooals v. d. K. van De Vries overnam, zie verder Encyclopaedie Ned. Indië s.v.: metrosideros vera. 
groeiende als een van hunne regulatiën [hier zet Van der Kemp twee vraagteekens] beschouwd worden moet., 1

Duidelijker vind ik deze theorie terug in een Extract Besluit van Commissarissen tot de Overname van 2 Augustus Nr. 117 dus midden in den opstand.

Zal dit besluit straks in andere opzichten blijken een herziening te bevatten van hun standpunt - na de opgedane ervaring? -, voor de houtlevering wordt daarbij nochtans ‘besloten deze te continueeren op de presente voet en wijze van betaling, daar dezelve beschouwd moeten worden als Landsdomeinen als wordende op Gouvernements grond voortgekweekt. *

Voor Van der Kemp zou dit misschien geweest zijn een "niet onaardig gevonden» argument, afkomstig uit 't brein van den "leuterenden" Engelhard of uit diens "buitengewoon omvangrijk huisarchief» - omvangrijk ook al was, volgens Dr. de Haan, daarin niet veel ontwikkeling verzameld, maar den Landraadsvoorzitter, die in zijn ooren nog hoort de stem van Professor Van Vollenhoven en die diens "Miskenningen van het Adatrecht" alsmede zijn "Eeuw van Onrecht den Indonesiër in zijn Grond aangedaan» onderschrijft, zegt dit meer: niet alleen ziet hij daarin de voortzetting van Raffles' theorie, welke "voor diens schandalig hooge landrente heel Java decreteerde te zijn een pachthoeve van het Gouvernement»; doch ook ziet hij daarbij als in het verschiet de nog steeds gehandhaafde, echter zeer aangevochten agrarische domeinbeginselen, vervat in de Indische Staatsbladen van 1870 en 1875 , veel bestreden beginselen, welke - om een woord van Van Vollenhoven te bezigen "nu nog in het dagelijksch leven eindeloos veel malen tegen Indoneesche rechten op grond als gewetensstopper worden uitgespeeld».

Hoe groot was dan dat loon? Vooraf de opmerking dat niet het bedrag bij tarief bepaald, zelfs niet het bedrag dat het volk in de hand ontving, mij het belangrijkst voorkomt - zeker, de Gouverneur moest zuinig zijn, trouwens, waarvan zou hij royaal zijn? - maar wat het meest drukte, was het zware werk voor zoovele verplichte leveringen.

De vraag luidde: hoe groot was dan dat loon?

Van Middelkoop blijft als een goed advocaat in het vage

1 v. d. K. 1919 , bl. 160. 
door te spreken van «een billijk loon». De Zendeling De Vries noemt 40 of 50 cent $^{1}$ en vindt dit te gering "voor een paal of balk gekapt op Ceram, gekeurd op Sarapoera, afgeleverd aan het fort te Ambon». Ik echter acht me gelukkig uit het door mij gevonden Secreet Besluit van 12 April L. A. A. $n^{\circ} 36$ «houdende Prijscourant voor te Leveren Houtwerken en andere artikelen» - waarom geheim?! ons dunkt juist dat zoo'n tarief zoo publiek mogelijk moet zijn - te kunnen overschrijven:

voor een balk 6 duim dik

lang 12 tot 18 voet. . . . . . . . . . . ropijen 2.16

idem onder de 6 duim dik

lang 8 tot 12 voet . . . . . . . . . . . . " 0.18

plank $1 \frac{1}{2}$ duim dik

lang 12 tot 18 voet. . . . . . . . . . . " " 0.18

idem boven $1 \frac{1}{2}$ duim, lang na evenredigheid . " " $2 .-$

paal van nanyhout . . . . . . . . . . " " 2.-

palisade . . . . . . . . . . . . . . . . .

100 atappen. . . . . . . . . . . . . . . .

100 gaba gaba. . . . . . . . . . . . . . . .

Dit dan was de betaling die men, voor zoover ressorteerende onder het hoofd: Kasteel Nieuw Victoria, ter Hoofdplaats ontvangen kon door khet reçu van den Genieofficier, gecontrasigneerd door den superintendent der Negorijen aan den Algemeenen boekhouder aan te bieden, ter afgifte eener kasordonnantie», dus een verwijzen van het kastje naar den muur.

Was voor Ambon de uitbetaling omslachtig geweest, op de Buitenposten mocht de Resident eerst uitbetalen "na van den Gouverneur kwalificatie te hebben verkregen om het bedrag bij zijne kasrekening te mogen afschrijven». En dan nog in papiergeld, waarover straks meer.

$\mathrm{Na}$ het uitbreken van den opstand heeft men hierin dadelijk verbetering gebracht.

Bij Besluit van 24 Mei - op Saparoea was 14 Mei de opstand begonnen - werden den superintendent der Negorijen gelden in handen gegeven "ter goede rekening ter onmiddellijke uitbetaling aan leveranciers».

Hoe ging 't met de betaling op Saparoea?

1 V. d. K, 1915 bl. 58. 
Men klaagde dat de Resident, 28 jaar oud, kersversch uit Holland, aan den leiband liep van zijn schrijver. Maar zou dan heusch de negorijman ten slotte van de 2 ropijen volgens tarief voor een paal van nanyhout slechts 40 of 50 cent in handen hebben gekregen, zooals De Vries vertelde? ${ }^{1}$

Matulessy zegt: «Wij, het volk, kunnen geen papierengeld gebruiken in het dagelijksch leven. Weigeren wij het van het Gouvernement te ontvangen, dan worden wij streng gestraft, willen wij bij den lijnwadenwinkel met papier betalen, dan wordt het geweigerd.» Bij de aankomst der tweede expeditie luidt het evenzoo, "dat de Resident weigerde het papiergeld in ontvangst te nemen en voor betalingen aan den Lande zilveren specie verlangde».

De levering van dengdeng, waarover op Saparoea ook is geklaagd, was blijkens Besluit van 30 April bestemd voor "de Nassau» en wel 1000 pond, waarvan te leveren 300 door Saparoea, 500 door Hila en 200 door Haroekoe, tegen 24 ropijen de picol "volgens bekomen informatie de gewone prijs".

\section{Verplichte diensten.}

Daar komen nog bij de verplichte diensten. Den $3^{\text {den }}$ Mei vroeg de Resident van Saparoea aan Commissarissen hem te willen «elucideeren of den scheppers voor de menigvuldige» let wel - "orang bays ten dienste van het Gouvernement voor het overbrengen van goederen, manschappen of brieven, een daggeld van vier stuivers per dag per hoofd moest worden geaccordeerd, zooals bij het Britsch Bestuur, zijnde bij het voormalig Hollandsch Bestuur geene uitbetaling aan hen gegeven». Het antwoord van Commissarissen is mij helaas niet bekend. Slaan wellicht hierop de klachten van Matulessy: "voor het overbrengen van de post naar Ceram wordt maar vier gulden betaald, voor die naar Ambon maar twee gulden, dat is toch al te $\operatorname{erg}$ !

In het genoemde Besluit van 2 Augustus - let wel na de

1 V. d. K. 1915 bl. 58 wien dit tarief niet bekend was, onderscheidde niet "paal" van „palissade". 's Gouverneurs Order van 12 April 1817 luidt tot levering van "palissaden" voor 's Lands Werf te Ambon, zooals ook wordt bevestigd door het maleische Rapport van den Schoolmeester van Porto v. d. K. 1911 blz. 580. - De opmerking van De Vries slaat dus niet op de lading palissaden, weer uit de prauw gehaald, waarmee de opstand begon, maar op de "palen". 
Sarapoea-ervaring - zijn Commissarissen hieromtrent duidelijk tot inkeer gekomen. "Aan negorijvolkeren geëmployeerd in gouvernementsdienst op de orengbays tot het overbrengen van goederen, manschappen of brieven wordt toegelegd vijf stuivers daags en de gewoonlijke randsoenen wanneer zij uit de baai over zee gaan, maar in de bay of op het eiland blijvende, vier stuivers daags zonder meer, waarvan op verzoek een gedeelte in dezelve afwezigheid kan worden afgegeven aan de vrouw of kinderen tot derzelver subsistentie.»

Ook het vervolg is merkwaardig: "Den superintendent wordt ten serieusten gerecommandeerd te zorgen dat deze drukking egaal kome over de negorijvolkeren en niemand, wiens beurt het is, door afkoop daarvan worde geexcuseerd, waaruit moedeloosheid voor de anderen zoude kunnen ontstaan en aanleiding geven tot Commotie, terwijl hij alsmede zijn attentie zal vestigen en zorgen dat de zulke die personeele diensten hebben gepresteerd of materialen geleverd, daarvoor prompte betaling ontvangen en niet worden tekort gedaan, alzoo in contrair geval hij daarvoor verantwoordelijk wordt gehouden.»

Naast deze al zoo zware verplichtingen hebben de proefjes met zoutaanmaak, notencultuur en koffielevering de stemming helpen bederven.

Het hoofdeiland Ambon is, behalve de streek Hila-Larike op Noord-West Hitoe, niet in opstand gekomen.

Ligt dat misschien aan den volksaard? ${ }^{1}$ Ook nu nog staat Saparoea bekent als lastig te besturen en geldt dit in 't bijzonder dezelfde negorijen n.l. Maria en Porto, terwijl ook thans weder het heele eiland Noesalaoet in den volksmond tedoeh (kalm) heet.

$\mathrm{Nu}$ mij voor Ambon zooveel gegevens ten dienste staan, geef ik ook deze uitvoerig ter karakteristiek van den

\section{Geest der Bestuursvoering.}

Uit het Besluiten-register blijkt, dat de houtleverende negorijen ressorteerende onder het Hoofdkasteel Nieuw-Victoria het hard hadden te verantwoorden. Nergens een spoor dat, tegenover de tallooze aanvragen der Militaire Overheid, de Gouverneur eens opkwam voor de belangen zijner bevolking. Als de Gouverneur soldaten alleen voor de Molukken kan vinden, keurt de Militaire

1 Vergel. v. d. K. 1915 bl. 23. 
Commandant dit af "wijl een soldaat verplicht is te gaan, werwaarts de Souverein hem noodig heeft ${ }^{1}{ }^{1}$

Steeds weer wordt de Superintendent der negorijen gelast dan weer dit, dan weer dat "bijwege van verdeeling over de verschillende negorijen te verschaffen .

En veel, ontzettend veel bleek er noodig: palissaden voor de Marinewerf, groote reparaties aan het Kasteel, aan het Militair Hospitaal, aan de gebouwen op Banda en de kleine posten op het eiland Leitimor; zelfs brandhout voor de pas aangekomen oorlogschepen, eerst 20 vaam voor de Nassau, daarna 36 voor de Reygersbergen "per vadem van zes voet in 't kubiek te betalen met vier ropijen»; toen de Chineesche aannemer moeilijkheden kreeg met de vleeschvoorziening voor de troepen moest ook hiervoor de superintendent te hulp komen; voor het geregeld verkeer met de pas Bengoala moesten, weer bij verdeeling onder de negorijen, steeds op eerste rekest van den Militairen Commandant twee orembays disponibel zijn, zooals het Besluit verder zegt, «evenals vroeger onder het Hollandsch Bestuur, welke verplichting door het Engelsch Bestuur als onnoodig niet was in stand gehouden .

Het nieuwe Bestuur liep geweldig van stal.

Nette Hollanders als wij zijn, moesten al bij Besluit van 19 April de wegen in de kota grondig worden hersteld en werd de stadsreiniging opnieuw geregeld. Bij Besluit van Commissarissen van 25 April werd de politie, die den Engelschen jaarlijks 7 à 8000 Spaansche matten had gekost, vervangen door nachtwachten van bewapende burgers, "kunnende een diergelijke lastpost niet wel worden gecontinueerd». Voorts waren blijkens Besluit van $1 \mathrm{Mei}$ "geene gemakhuizen ter hoofdplaatse, zoodat goten en waterleidingen alsware met vuil opgevuld waren", en aan de «ongelitimeerde vrijheid onder het Engelsch Bestuur om zijn nabestaanden op eigen erven of tuinen te begraven» werd een eind gemaakt. De inenting werd weer dadelijk ter hand genomen; het vaccinatie rapport noemt 57 kinderen ingeënt, ‘waarvan bij 27 bekend is dat de vaccinatie gevat heeft, 24 niet ter examinatie zijn teruggekomen, terwijl bij 6 de uitslag nog niet bekend is». Ook verrezen in de stad twaalf nieuwe schilderhuizen, en een wachthuisje bij de woning van Magistraat Roseveld en werd

1 V. d. K. 1919 bl. 162. 
de burgerwacht "onder de Engelschen alleen, met zeer slechte pieken bewapend, nu weer als onder het voormalig Hollandsch Bestuur, van behoorlijk schietgeweer en andere wapenen voorzien «. En als het niet alles zoo somber was afgeloopen, hoe model klinkt dan niet een maatregel van 20 April:

-In aanmerking nemende, dat zoowel voor het Gouvernement ten gebruike als voor de natuurlijke Historie tot vermeerdering van Kennis en Wetenschap van het uiterste belang aangemerkt worden moet, dat van alle medicijn, benevens Scheeps-, Timmeren Meubelhout bekend worde dezelver wezenlijke naam, aart en kwaliteit ;

Is besloten tot een exact en nauwkeurig onderzoek, houdende een descriptie van dezelver naam, zoo in eigenlijke landtale als in het Hollands en Maleids, benevens aart, gebruik en eigenschap, als wijze van aanplant en voortkweeking; en wordt wijders gelast den Gouverneur te zenden een gemaakt boekje in dewelke zich behoorlijk gedroogd en wel geconserveerd zal moeten bevinden een klein takje met de bladeren, de vrugt, het zaad of bol en bast nevens de gom of harst van ieder gewas.,

Een ander Besluit van 1 Mei had de cultuur van oebis of potattos weer omhoog willen werken, «die op Ambon aan deugd en smaak met de Javaansche gelijk staan, ja zelfs die van sommige districten overtreffen .

\section{Het papierengeld.}

Hoe hoogdravend waren Commissarissen-Generaal begonnen in hunne Publicatie van 14 Januari 1817: "Zoo toch Zijne Majesteit Nederlands geldelijke :toestand op een onwrikbaren grond heeft gevestigd, $\mathrm{Hij}$ heeft ons last gegeven Nederlandsch Indië een gelijk voorrecht te doen genieten en ons daartoe uitgerust met aanzienlijke middelen, die, wel besteed een ruimen onafgebroken omloop van geld verzekeren. Ruim twee millioenen schats zijn ons in klinkende specie medegegeven; dan, daartoe bepaalde zich des Konings zorgen niet.

"Hij beval om een ander middel van gestadige geldomloop te bezigen, het aanmaken n.l. van een papieren munt, die door hare uiterlijke voortreffelijkheid en wezenlijke waarde met de klinkende een gelijken tred loopen zou.

«Op al deze gronden verklaren, bepalen en bevelen wij: dat de papieren munt nimmer voor des Lands rekening tot een 
andere, hetzij hoogere of lagere waarde zal worden aangenomen of uitgegeven dan op dezelve is uitgedrukt, en dus nooit dan gelijkstandig met de klinkende munt waarvan zij een volkomen representatief is.

"Dat deze papieren munt dagelijks zal kunnen worden ingewisseld tegen andere papieren of ook tegen klinkende munt naar verkiezing des houders .

Och! wat een ijskoude douche heeft de praktijk over deze warme ontboezeming uitgestort! Over de onjuiste grondslagen van het heele muntstelsel, over de onbevoegdheid in dezen ook van de vooraanstaanden in den lande, over het geldgebrek van Commissarissen-Generaal en onze Moluksche Commissie heeft Van der Kemp sombere bladzijden geschreven. ${ }^{1}$ Voor zoover onze opgave betreft: n.l. de oorzaken van den opstand, gezien van onderaf uit de ervaring van het volk aan den lijve, komt hij uit de Rapporten van Van Middelkoop zelf en van Buyskes tot de conclusie, "dat de papieren gulden feitelijk niet verwisselbaar was; de gansche groote Oost kreeg niet meer dan drie verwisselings kantoren, terwijl de papieren munt in circulatie was gesteld zonder vooraf het kantoor voor de verwisseling georganiseerd en opengesteld te hebben. ${ }^{2}$

En hier weer datzelfde te kort aan bestuurskunst. In 1810 waren wij schandelijk weggegaan na een papieren noodmunt "die door geweld gangbaar moest worden gehouden» (Buyskes), nu begonnen we waarachtig al dadelijk evenzoo. En zulks wisten Commissarissen zeer wel! Van Middelkoop zeide zelf: "Sedert het Engelsch Bestuur hadden er Spaansche matten gecirculeerd en hierop was men verlekkerd., En nu blijkt, dat men ook van Banda uit gewaarschuwd was; 9 April toch schreef Resident Berkhoff: "Voor het tegenwoordige reken ik mij niet bevoegd eenige uitbetaling in papier te beginnen zonder een voorafgaande aandringende en verzekerende publicatie te voorschijn te kunnen doen komen bij gebreke van welke misschien discrediet en agietage veroorzaakt zouden worden, vooral te vreezen in deze gewesten alwaar vorige ondervinding zulk een diepe indruk heeft nagelaten.»

Nadat deze Resident "op 12 Mei na een toenemende ziekte van slechts vijf dagen tot ons aller droefheid in den Heere is ontslapen», kon Magistraat Van Aart, een geboren Bandanees,

1 V. d. K. 1913 hoofdst. II blz. 97, hoofdst. III blz. 191.

2 V. d. K. 1915 blz 26, v. d. K. 1919 blz. 157. 
als wnd. Resident de Heeren in Ambon nog beter inlichten: - Het lot van het voormalige papier van credit is zeer deplorabel als hebbende daardoor velen geleden, waarvan de ondergeteekende de grootste lijder is geweest. Weshalve ik zoo vrij ben U.H.E.G. een korte opgave aan te bieden" - men kan nooit weten! Of hij daarmede succes heeft gehad, is niet bekend, wel vertelt Van der Kemp dat Van Aart als waarnemend zich het zware tractement van $f$ 2000._ 's maands van Resident Berkhoff eigener autoriteit deed uitkeeren. ${ }^{1}$

\section{Hervorming Schoolwezen.}

Geven mijne archiefbundels over de werving voor den militairen dienst geen nieuw licht, over de hervorming van het schoolwezen meen ik een kleine verheldering te kunnen geven. In zijn laatste bewerking is de slotsom van Van der Kemp edat hiertoe de zucht tot verlichting van 's Lands kas de drijfveer was geenszins het verlangen om het onderwijs te verbeteren. ${ }^{2}$ Uit een brief van Van Middelkoop van 9 April zou ik echter afleiden, dat deze maatregel toch wel past in het systeem der hervormingswoede, al moest dit dan ook zoo goedkoop mogelijk ten uitvoer worden gelegd:

«De Gouverneur neemt in aanmerking, dat het publiek onderwijs der jeugd een der eerste en voornaamste pligten van den gebieder is, dat dit zich onder het afgetreden Britsch Bestuur eenlijk schijnt bepaald te hebben tot het Hoog-Maleisch, terwijl de ongelden daartoe van Gouvernementswege geïmpendeerd door mankement aan een bepaald generaal en geregeld oppertoezigt, geenszins aan de verwachting beantwoord hebben, weshalve van den Superintendent over de scholen, die der negorijen, de Kerkeraad der Hervormde Gemeente en verschillende Residenten een juiste opgave wordt gerequireerd van de presente staat der scholen alsmede de order en wijze van beheering. Waar geen Hollandsch onderwezen wordt moge dit ook in den aanstaande plaats vinden om alzoo de bewoners te nauwer aan het Moederland verbonden te doen zijn.»

In een brief van 15 April heeft de Resident van Saparoea zijn advies - afwijzend, let wel - breed gemotiveerd: shet heele schoolwezen zoude compleet te niet hebben geloopen

1 V. d. K. 1919 blz. 188.

: v. d. K. 1919 blz. 161. 
indien daarin niet ware voorzien geworden door dat het Britsch Bestuur de meesters weer van Compagnieswege salarieerde» de Franschen hadden dit in 1810 ten laste der negorijen zelf gebracht. "Door die verandering zoude een wezenlijk nadeel worden toegebracht. ${ }^{1}$

Van iedere hervorming is toen afgezien.

In haar Rapport van 28 April, dus vóór den opstand, schreef de Commissie naar Batavia «dat bij den Amboneezen de bedugting plaats heeft dat'veelligt kerk en school weder bij ons Gouvernement vermindert en verandert worden zals. Zoo zegt ook Matulessy: «Het Hollandsch Bestuur wilde de schoolmeesters ontslaan.»

Dat de bevolking reeds een onderzoek alleen zoo hoog opnam, had de Heeren ook bij andere maatregelen voorzichtig moeten maken.

\section{Maatregelen van Bestuur tijdens den opstand.}

Hoop ik nu over ieder der oorzaken eenig nieuw licht te hebben ontstoken, misschien kan dit nog worden versterkt uit eenige tot nu toe onbekende maatregelen van bestuur, die de Gouverneur, stapje voor stapje, tijdens den opstand heeft moeten nemen.

14 Mei was de opstand uitgebroken. 19 Mei schreef de Secretaris Von Schuler voor H.H. Commissarissen een Engelschen brief aan den Superintendent of Schools - van de Britten overgenomen ${ }^{2}-$ "Schoolmasters through their peculiar situation have generally a great authority on the mind of people whose children they instruct, particularly so in the Moluccos.

«It is the Governors wish therefore that you should caution them to be on their guard against the snares of malice and fraud and to exert your utmost endeavours in keeping the natives quiet and faithfull to their lawfull sovereign, for by doing this, happiness and plenty will be secured to them, whereas if military force is used, notwithstanding all precautions to the contrary poverty ruin and distress will be their lot."

Niets werd verzuimd.

Bij Besluit van 28 Mei staan Commissarissen den Gouverneur $f 500$ toe om "premies uit te loven of geschenken te doen aan

1 V. d. K. 1915 blz. 29.

2 Zie uitvoerig v. d. K. 1911 blz. 451. 
personen, welke zich aanbieden tot het inwinnen van informatiën omtrent de rebellie van Saparoea». Bij besluit van 29 Mei werd de Gouverneur der Moluccos «door Commissarissen gekwalificeerd om te doen afgeven uit Gouvernements Pakhuizen zes ellen wit vlaggendoek, aangezien het raadzaam is bevonden vreedsame middelen te beproeven om de muitelingen tot hunne plichten terug te brengen; daartoe is het noodig de personen uitgekozen om met de rebellen te aboucheeren van vredevlaggen te voorzien.»

20 Mei verscheen een

\section{Proclamatie :}

"Te ooren gekomen zijnde, dat eenige kwalijkgezinden de ingezetenen hebben trachten diets te maken dat dezelve onder het presente Nederlands Gouvernement geen betaling zullen erlangen voor de door hen geleverde houtwerken en andere materialen, alsmede dat ten aanzien der Christenen evenals weleer de schoolmeesters zullen afgedankt en omtrent de Mohamedanen, dat die verplicht zouden worden de leere van Christus te moeten aannemen en eindelijk, dat weder, als onder het Bestuur van de Heeren Cranssen en Wieling heeft plaats gehad, een geforceerde werving van militairen geschieden zoude.

Is besloten,

in naam van het Nederlands Gouvernement, de verzekering te geven:

« $1^{\mathrm{e}}$. dat gene leverantie gevorderd worden zal dan tegen zoo danige betaling als die onder het Britsch bestuur heeft plaats gehad, en bepaald is bij ons Besluit van 12 April;

< $2^{\mathrm{e}}$. dat ten aanzien van het schoolwezen onder de Christenen geen veranderinge door het afdanken of verleenen van ontslag aan eenige der schoolmeesters plaats hebben zal;

« 3 e. dat in den Eeredienst des Heeren zoo ten aanzien der Christenen als Mohamedanen geen verandering veel min eenige infractie gemaakt worden zal door een andere godsdienst onder dezelve in te voeren of de Mohamedanen te verplichten de leere van Christus te moeten omhelzen maar dat aan een ieder een volkomen vrijheid van godsdienst en geweten gelaten en verzekerd worden zal;

\&4 $4^{e}$ dat ook geenszints de intentie van het gouvernement is om den inwoonders door een geforceerde pressing tot de Militaire dienst voor Batavia te verpligten en alzoo op een gewelddadige 
en willekeurige wijze van hunne familiën af te scheiden en te verwijderen, maar wel om door een vrijwillige aanwerving onder het uitleveren van een billijk handgeld in het bijzonder de zoodanige welke altoos langs dien weg haar bestaan zoowel onder het voormalig Hollandsch als jongstafgetreden Britsch Bestuur gevonden hebben te engageeren alszoodanig in dienst van $\mathrm{Zijne}$ Majesteit den Koning der Nederlanden over te gaan en zich zelve alzoo in stede van werkeloos mede te loopen en òf uit behoefte ò uit verregaande boosheid en baldadigheid door afpersing of ontvreemding van het noodwendige aan hunne familiebetrekkingen of andere medenatuurgenooten tot last te zijn van een vast bestaan te verzekeren.

« $5^{\mathrm{e}}$. om de zoodanige welke niet genegen mogten zijn tot den militairen dienst over te gaan door zagte en gepaste middelen te overreden weder tot hunne negorijen en woonplaatsen terug te keeren om aldaar als stille en vreedzame ingezetenen door hunne handenarbeid met den landbouw een genoegzaam bestaan voor hun en voor hun kinderen te vinden.»

Om even uit deze lange Rede der kurze Sinn op te diepen: de gedwongen leveranties bleven gehandhaafd, zoo ook de prijzen op 12 April vastgesteld (hetgeen mij versterkt in mijn indruk, dat deze officieele prijzen wel behoorlijk zullen zijn geweest), en duidelijk werd verder den heet gebakerden Saparoëeezen voorgehouden, dat aan het onderwijs niet zou worden getornd.

Wat de vrijwillige werving voor Java betreft, gaf de gouverneur de hoop dienaangaande te slagen nog niet op, nu hij getracht had de vrees voor een geforceerde recruteering voor Java weg te praten. De grootste angst der bevolking was immers geweest dat dit spelletje van Daendels van 1810 zich zou herhalen.

Toch gaf ook dit niet! Van het korps 400 man sterk, dat de Engelschen alleen in de Molukken hadden laten dienen, ${ }^{1}$ lieten zich slechts 33 overschrijven voor Java. 9 Juni gaf de Commissie ook hierin toe en cliet het engagement toe om weer drie jaren in de Molukken dienst te presteeren, met last tot dat einde in eenen af te geven het handgeld daarvoor bepaald.

Bleven, zooals we zagen, de leveranties en de prijzen daarvoor onveranderd, toch valt in de wijze van uitschrijven langzamerhand een merkwaardige verandering op!

1 V. d. K. 1915 blz. 16, id. 1919 blz. 161. 
Heette dat vroeger eenvoudig "opdracht aan de Superintendent ter verdeeling over de Negorijen", in een Besluit van 12 Juni worden voor het eerst soort en afmetingen der houtwerken één voor één omschreven, welke de Superintendent «evenredig en billijk zal verdeelen.» 18 Juni wordt gelast «een billijke verdeeling overeenkomstig de bevolking van iedere negorij en de nabijheid der bosschen alsmede naar mate een ieder derzelve van deze houtwerken is voorzien en in onderling overleg met de gezamenlijke Regenten, ten einde alle misnoegen of bezwaren deswege voor te komen.s

Met den dag wordt dan de toon aangenamer om aan te hooren: 20 Juni wordt den Superintendent opgedragen «om onder het betragten van een goede en voorzichtige politiek het met de Regenten daarheen te dirigeeren dat zonder de gemeene man te veel te bezwaren de geschikte materialen bijeengebracht worden.,

Op 26 Juni wordt het hoogste punt bereikt! dan gaan zelfs de koorden der beurs los!

Voor de Maria Reijgersbergen moet 36 vadem brandhout geleverd worden stegen een verhoogde betaling van twee ropijen de vadem, in aanmerking van de meerdere werkzaamheden, waartoe de negorijbewoners door de onlusten op Saparoea verplicht zijn en zulks als een extra-douceur van het Gouvernement ten blijk van hare geneigdheid om in deze prezente oogenblikken de ingezetenen naar vermogen tegemoet te komen.»

Den $2^{\text {den }}$ Augustus hebben ook Commissarissen zich bezonnen over eventueele bestuursfouten. Hun besluit bespraken we reeds, voor zoover het betrof de leveranties van houtwerken en andere materialen en de verplichte diensten als scheppers op de orembays. Daarbij werd verder besloten:

*1e. Vooreerst geen verandering te maken in de door de Regenten geleverd wordende manschappen uit de negorijen tot de werkzaamheden van het Gouvernement, tot zoolang als door Hunne Excellenties Commissarissen Generaal daar in zal zijn voorzien, hetzij door inhuur van een toereikend getal Javanen om alhier dienst te doen of het herwaarts zenden van een toereikend getal kettinggangers of bannelingen.

« 5 e. dat ook voor eerst en tot nader order van H.H. Excell. Commissarissen Generaal de Regenten het gebruik zullen behouden van de kwarto lieden in zoodanig getal als van oudsher 
een ieder is geaccordeerd geworden zonder betaling, zijnde het overigens ieder particulier zonder onderscheid verboden gebruik te maken van negorijvolkeren andere dan zich daartoe vrijwillig engageeren en tegen behoorlijke betaling .

Terwijl den meermelden superintendent aanbevolen wordt "alsmede een wakend oog daarop te houden, dat geen misbruik hiervan wordt gemaakt of dat de Hoofden door meerder volk te pressen of daarvan meerdere diensten te vorderen dan billijk is geen aanleiding geven tot misnoegen in de negorij.

«En bij de minste overtreding daarvan met den meesten spoed kennis te geven aan den Gouverneur der Molukken om niet alleen dadelijk daarin te voorzien maar de schuldige naar exigentie van zaken daarvoor te corrigeeren.»

Zoo kreeg dus de Superintendent der Negorijen eenigen goeden raad mee. Maar hoeveel bleef bij de uitvoering niet aan het beleid van dezen overgelaten!? Daarom juist is het te betreuren dat zoo weinig bijzonderheden van dit ambt en vooral van den ambtenaar zelf bekend zijn. ${ }^{1}$

22 Maart benoemden Commissarissen provisioneel den Heer J. L. P. Rijcke, van wiens persoon en praestaties geen teekenende feiten worden verteld.

Van Middelkoop wilde geen specialen ambtenaar maar den Hoofdadministrateur, den Heer Croese, er, mee belasten. Is dit gebeurd? zoo ja, dan zou men, volgens Van der Kemp daarmee slecht af zijn geweest. ${ }^{2}$ Pijnlijker nog is de onzekerheid, wanneer dat dan zou zijn gebeurd: nog vóor het uitbreken van den opstand of toen de vlammen al hoog opsloegen?

In ieder geval 8 November hief Buijskes het heele ambt op.

1 V. d. K. 1911 blz. 385, 1919 blz. 171, 184.

2 V. d. K. 1911 blz. 370 . 


\title{
BIJLAGE.
}

\section{EXTRACT uit het Register der Handelingen en Besluiten van den Gouverneur der Moluksche Eilanden.}

\author{
Donderdag den 14 Augustus 1818.
}

In aanmerking genomen zijnde, dat het zeer noodzakelijk is, dat aan de Inlandsche Hoofden Radjas, Pattys en Orangtouas, zoo wel onder het kasteel Amboina als onder de Subalterne kontoiren gehorende een Instructie werde gegeven; daar de oude Instructie zedert een geruimen tijd niet is vernieuwd, en verscheidene orders en regulatien bevat, welke thans niet meer kunnen worden opgevolgd en ook wijders in aanmerking genomen zijnde dat overmits door de jongste onlusten veel nieuwe Regenten zijn aangesteld, welke met de oude Instructie in het geheel niet bekend zijn.

Is goedgevonden en verstaan:

onder de approbatie van zijne Excellentie den Gouverneur Generaal te arresteren gelijk gearresteerd wordt bij deze de navolgende

PROVISIONELE INSTRUCTIE voor de Radjas, Pattys en Orangkajen zoo onder het resort van het Hoofdkasteel Amboina als op de onmiddelijk onder Amboina gehorende Residentien.

\section{ART. 1.}

De Gezamentlijke Inlandsche Hoofden zullen onder het hoger gezag van den Gouverneur der Moluksche eilanden hunne onderhorige bestieren op een zagte betamelijke wijze, zonder omtrent dezelve enig geweld en knevelarijen, veel min wreedheden te plegen; maar hun op een bescheiden wijze tot hun plicht aanzetten, alle ongeoorloofde handelingen zoo veel moglijk beletten, en van alle voorvallen of geschillen van enig belang kennis geven, hier op Amboina direct aan den Gouverneur en op de Residentien aan de Residenten, Civiele Commandanten of opzichters, om door deze naar vereischt van zaken beslist, dan wel aan den Gouverneur gerapporteerd te worden.

Dl. 79. 
ART. 2.

De Christen Regenten zullen omtrent de oeffening, en onderhouding van het christelijk geloof alle ijver en naarstigheid in het werkstellen, nevens hunne familien, kapala soas en orangtouasch, de minderen in leven en wandel met een goed voorbeeld voorgaan zoo in de bijwooning van den openbaren Godsdienst, het houden der jeugd tot de school oefening als tot het weeren van aller hande bijgelovigheden en afgodendienst, strijdig met de Christelijke Religie zoo min als alle hatelijke twisten met de zulke die van een ander godsdienst zijn waarom ook op zodanige plaatzen daar zich beide, Chistenen en Mohamedaanen bevonden, den een den ander niet zal mogen molisteeren maar een ieder zijn Godsdienst ongestoord verrigten.

ART. 3.

Geen Mohamedaan zal met eene Christene vrouw, of een Christ met een Mohamedaansche vrouw vermogen te trouwen, noch in concubinatie te zamen mogen leven. Terwijl tot wering van alle correspondentie en te naeuwe connectie van den Cerammer met den Inlander van de Nagel districten het verboden blijft dat Cerammers zich in huwelijk of concubinagie mogen engageeren met vrouwen of dochters in de Nagel districten te huishorende en zoo ook wederkerig geen mannen van de nageldistricten met Ceramsche vrouwen of dochters.

ART. 4.

De Regenten zullen hunne onderhorigen met geen andere diensten mogen bezwaeren of enige andere lasten opleggen dan de geene waartoe zij van ouds verpligt zijn en uit welken hoofde bij de gewoone en aan ieder der drie hoofd-Radjas onder Amboina toegestane vijf kwartslieden en vier of minder zoo de negorijen zwak zijn voor de overige Regenten zoo hier als op de onderhorige Residentien zal moeten gebleven worden; om dezelve tot hunnen dienst te gebruiken mits smaandelijks verwisselende, zonder bovendien enig volk op de Bayleow te mogen houden; onder gemelde oude gewoonte is verder ook begrepen het verlenen van assistentie door het Negorijs volk om in de tijd van den Nagel pluk twee maal sweeks voor hunne regent te moeten plukken zonder enige andere beloning daarvan dan slechts de mondkost op die dagen te genieten. 
ART. 5.

De Inlandsche hoofden moeten zorgen dat door hunne onderhorigen de kwartdienst voor het Gouvernement zonder verzuim worde verrigt en dat niemand dezelve onder het een of andere voorwendzel tragte te ontgaan waarom ook geintirdiceert wordt het zamenwoonen van onderscheiden familien of huishoudings in één en hetzelfde huis om het voor één huisgezin te doen door gaan maar zullen in tegendeel alle getrouwde lieden met hare familie elk op zich moeten woonen, en een iegelijk zijn eigen daty dienst moeten doen op poene van correctie.

ART. 6.

En aangezien het willekeurig verlaten der Negorijen veel al om die reden geschiet zal daar op naeuwkeurig agt geslagen en geenzins toegelaten worden dat iemand hunner onderhorigen derzelven negorij verlaten, zich naar andere districten ter woon begeven of als moerits bij den een of andere in dienst gaan ten zij alvorens van hunne regenten schriftelijk permissie daartoe erlangd hebbende, onder de goedkeuring hier te Amboina van den Gouverneur en op de onderhorige Residentien van de respective Residenten.

\section{ART. 7.}

Om voorgemelde redenen zullen ook gene hutten in de Bosschen of $\mathrm{Ruma} \mathrm{Kabongs} \mathrm{mogen} \mathrm{opgebouwd} \mathrm{en} \mathrm{getollereert} \mathrm{worden}$ dan alleen bij den nagel inzaam om voor de zon en regen bevrijd te wezen, welke echter zodra de Nagel pluk afgelopen is wederom moeten afgebroken worden, mogende geen huizen buiten de negorijen opgerigt blijven staan, maar moeten de zelve gesloopt of in den brand worden gestoken wanneer de order tot de afrekening gegeven is en dezelve echter nog zijn blijven staan zullende de Radjas en Pattys daar voor verantwoordelijk worden gehouden en degenen die zulks verzuimen aantegeven dan wel permitteeren of oogluikende toelaten van hun regentschap ontzet worden.

ArT. 8.

Ook zullen blijven standhouden de van ouds gewoone diensten bestaande op de buiten residentien en posten in het dekken der redouten, blokhuizen en het geene daar aan verder behoord, 
item het aanhouden en in gereedheid brengen van negorijs boegseer orembayen, in der specerij gevende districten voor elke Negorij en orembay, zo mede in het leveren van het nodige volk tot transport der Residenten van en naar hunne Residentien wanneer zij te Amboina in officie iets noodzakelijk te verrigten hebben of door den Gouverneur ontboden worden, voorts in het verzorgen van de nodige afmatting der Pakhuisen waarin de Nagelen geborgen ende schepen en vaartuigen waarin deze afgeladen worden, gelijk mede in het geneeren van manschappen tot het lossen en laden van Gouvernements bodems en wanneer het nodigt mogt zijn om die in of uit te boegseeren zullen dezelve voor alle zodanige diensten ieder 1 p. rijst en 3 stuivers sdaegs genieten.

\section{ART. 9.}

Die onder de post Manipa gehoren zijn bovendien ook nog verpligt ingevolge het met hun aangegaan contract op den 15 Februari 1622 tot het maaken, repareeren en onderhouden van het fort aldaar alle matterialen zoo van hout, kalk en steen en de daartoe nodige werklieden zonder eenige betalinge te moeten leveren met exceptie van het ijzerwerk en de nodige gereedschappen dewelke door het Gouvernement zullen worden verstrekt.

\section{ART. 10.}

De gewone kwarts dienst moet aan deze Hoofdplaats op de wijze als van oudsgebruikelijk door de Inlanders der onderhorige negorijen gepristeerd worden. En tot het in requisitie stellen van een getal van 125 manschappen zal de volgende repartitie in acht genomen worden over de gezamentlijke Negorijen onmiddelijk onder den resorte van het kasteel Victoria behorende, teweten :

$$
\begin{aligned}
& 10 \text { koppen van de Negorij Alang. }
\end{aligned}
$$

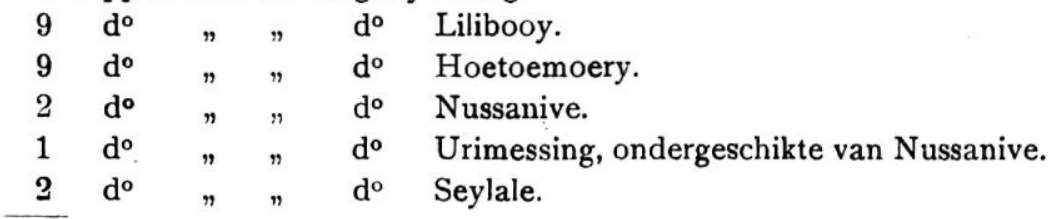

$$
\begin{aligned}
& 33 \text { koppen. }
\end{aligned}
$$




\section{3 koppen.}

\begin{tabular}{|c|c|c|c|c|c|}
\hline 4 & $\mathrm{~d}^{\circ}$ & van & $\mathrm{de}$ & Negorij & Groot Hative. \\
\hline 2 & $d^{\circ}$ & $"$ & $"$ & $\mathrm{~d}^{\circ}$ & Tawiri ondergeschikte van Hative. \\
\hline 3 & $d^{\circ}$ & $"$ & $"$ & $\mathrm{~d}^{\mathbf{0}}$ & Kielang. \\
\hline 3 & $d^{\circ}$ & $"$ & $"$ & $d^{\circ}$ & Nakoe, ondergeschikte van Kilang. \\
\hline 5 & $d^{\circ}$ & $"$ & " & $d^{\circ}$ & Hatalai. \\
\hline 1 & $\mathrm{~d}^{\circ}$ & $"$ & $"$ & $\mathrm{~d}^{\mathbf{o}}$ & Soya beneden en Soya boven. \\
\hline 1 & $d^{o}$ & $"$ & $"$ & $d^{\circ}$ & $\begin{array}{l}\text { Ahoesing en Amantelo beide ondergeschikt } \\
\text { aan Soya. }\end{array}$ \\
\hline 2 & $\mathrm{~d}^{\circ}$ & $"$ & $"$ & $\mathrm{~d}^{\mathrm{o}}$ & Halong. \\
\hline 3 & $\mathrm{~d}^{\mathbf{0}}$ & $"$ & $"$ & $\mathrm{~d}^{\circ}$ & Batoemera. \\
\hline 5 & $\mathrm{~d}^{\mathrm{o}}$ & $n$ & $"$ & $d^{\circ}$ & Hatoe. \\
\hline 6 & $\mathrm{~d}^{\circ}$ & $"$ & $"$ & $\mathrm{~d}^{\mathrm{o}}$ & Ema. \\
\hline 1 & $\mathrm{~d}^{\circ}$ & $"$ & $"$ & $d^{\circ}$ & Hoekoerila $\quad$ ondergeschikt van \\
\hline 2 & $\mathrm{~d}^{\circ}$ & $"$ & $"$ & $\mathrm{~d}^{\circ}$ & Roetong en Lahary $\quad$ Ema. \\
\hline 10 & $d^{\circ}$ & $"$ & $"$ & $\mathrm{~d}^{\circ}$ & Latoehalat. \\
\hline 2 & $\mathrm{~d}^{\mathrm{e}}$ & $"$ & $"$ & $d^{\circ}$ & Amahoesoe ondergeschikt aan Latuhalat. \\
\hline 7 & $d^{\circ}$ & $"$ & $"$ & $\mathrm{~d}^{\circ}$ & Soely. \\
\hline 1 & $d^{\circ}$ & $"$ & $"$ & $\mathrm{~d}^{\circ}$ & Christen Tial. \\
\hline 4 & $\mathrm{~d}^{\circ}$ & * & $"$ & $\mathrm{~d}^{\circ}$ & Mohamedaans Tial. \\
\hline 5 & $\mathrm{~d}^{\circ}$ & $n$ & $n$ & $\mathrm{~d}^{\circ}$ & Tenga Tenga. \\
\hline 15 & $\mathrm{~d}^{\circ}$ & $"$ & $n$ & $\mathrm{~d}^{\mathrm{o}}$ & Toelehoe. \\
\hline 10 & $d^{o}$ & $"$ & $"$ & $\mathrm{~d}^{0}$ & Waay. \\
\hline
\end{tabular}

$\overline{125}$ koppen te zamen als voorschr.

Welke bepaling echter ter discretie van den Gouverneur vermeerderd of verminderd zal worden naar mate der toenemende of afnemende bevolking der Negorijen en naar maten van de meerdere of minder werkzaamheden welke te Amboina te verrigten zullen wezen en waarvoor de gemelde kwartslieden genieten zullen 40 ponden rijst, en 3 Indische guldens ieder smaands.

\section{ART. 11.}

Terwijl op de onderhorige Residentien volgens het besluit van Zijne Excellentie den Heer Commissaris Generaal A. A. Buyskes, in dato 24 December 1817 het getal der kwartslieden op volgende wijze bepaald blijft, te weten

16 voor de Residentie Saparoea.

10 op Saparoea.

2 , Nussalaut.

2 " Hatawano.

2 "Porto. 


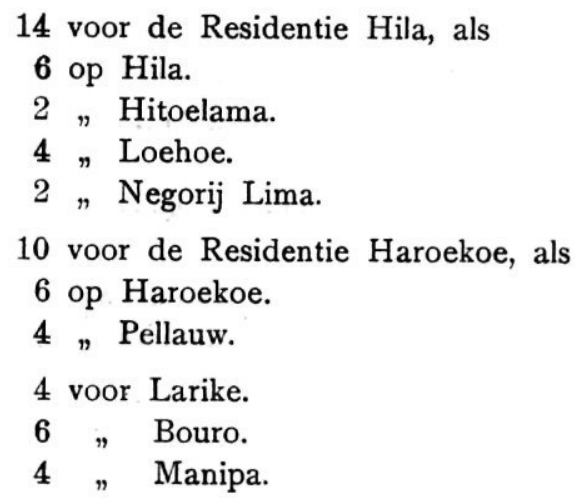

54 kwartsdiensten te zamen.

ART. 12.

Volgens gemelde zijner Excellenties besluit van den 10 Januari 1818 zullen de Negorijen Alang, Lilibooy en Hative elk beurtelings een schep Orembaay met de nodige manschappen op Alang moeten gereed houden ter dispositie van den opzichter dier post om hem aan boord der binnen komende schepen te voeren of enig narigt van die in het gezichtzijn naar het kasteel Victoria over te brengen, waartegen zij weder gelibereerd zullen zijn van het boegseeren der binnenkomende schepen anders dan bij hoge noodzakelijkheid en in welk laatste geval aan elk man 1 p. rijst en 3 stuivers per dag zal worden verstrekt.

ART. 13.

Van den eersten December tot den laatsten van Maart zullen de onder het Hoofd kasteel en onder Larike zorterende Negorijen elk gereed moeten houden een bekwame Orembaay met 15 man om op de eerste order, of een daartoe van boord van de aankomende schepen te doen seinschot er op uit te gaan en zich naar boord van zodanig schip te begeven ten einde het zelve bij stilte of andere gevaarlijke toevallen te helpen boegseeren en uit het gevaar te redden.

ART. 14.

De Inlandsche Hoofden zullen voorts gehouden zijn ingevolge de van de vroegste tijdens af op hun liggende verpligtingen om bij nodigheid het Gouvernement te moeten assisteeren en voorzien van houtwerken, kalk en andere materialen, voor zooverre een ieder zijn districten daar voor vatbaar is, en naar mate 
van derzelven plaatzelijke gelegenheid en populatie, tegen betaling van de ondervolgende prijzen te weten:

Voor 1 balk van kajoe bessie of ijzerhout,kajoe mera Samar of lengoa batoe, lang 21 tot $25 \mathrm{v}$. dik 9 tot $11 \mathrm{dm}$. $f 2.15$

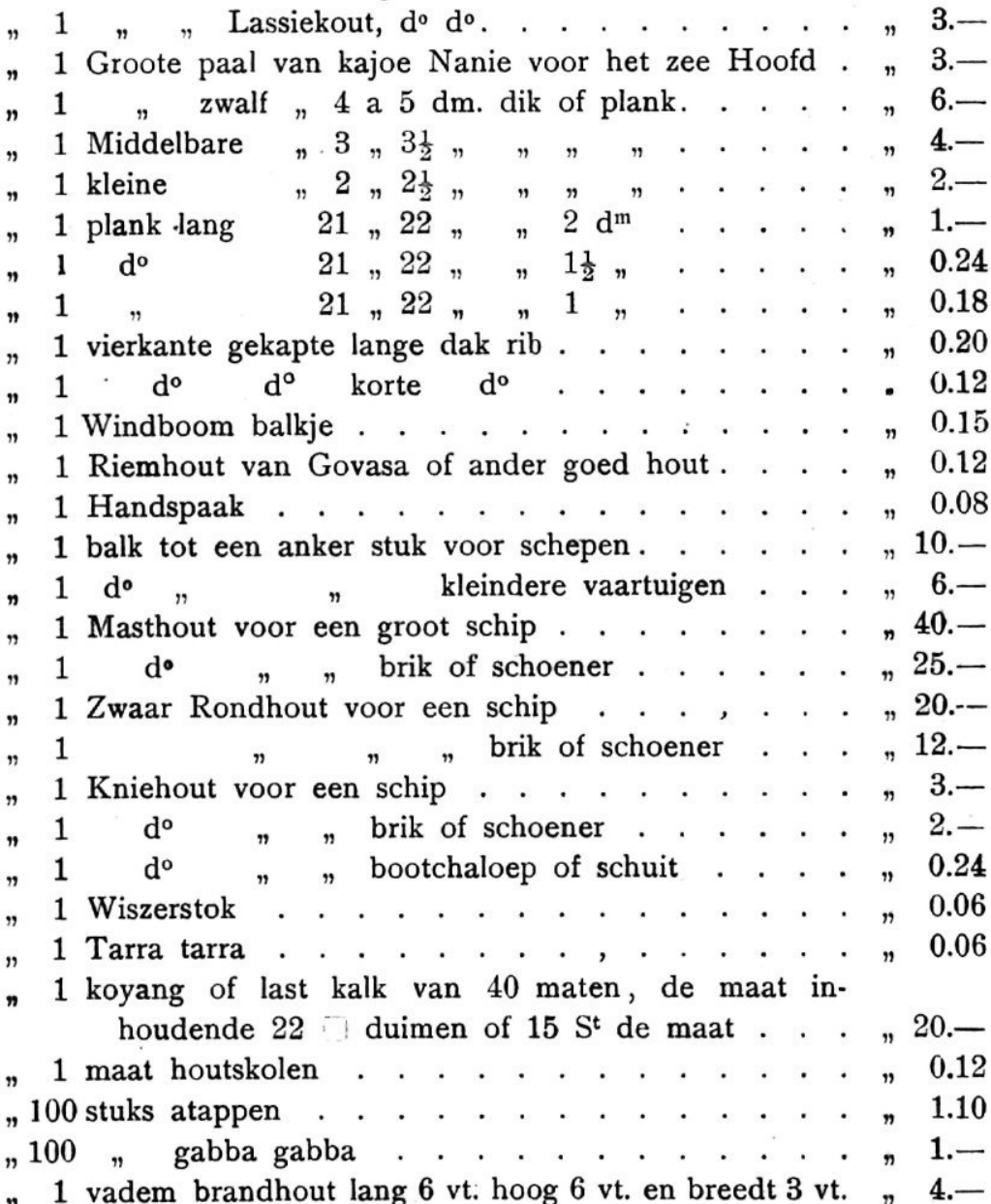

ART. 15.

Daar volgens het aloud gebruik jaarlijks indien zulks door andere bezigheden niet verhinderd wordt door den Gouverneur de Hongie togt gedaan zal worden, moeten de onderscheiden Negorijen onder resort van de Provincie van Amboina tegens den 15 October hunne kruys Orembaya aan dit Hoofdkasteel present hebben, en op elke kruys Orembaya zich de regent 
zelf bevinden of een der regenten indien meer negorijen te zamen scheppen, doch bij aldien siekte of andere omstande zodanig Regent verhindert wordende aan deze verpligting te beantwoorden moet in tijds daar van aan den Gouverneur kennisse worden gegeven.

\section{ART. 16.}

En vermits reeds sedert enigen tijd het gebruik van de zware cora-coras afgeschaft en dat van ligtere kruis Orembayen ingevoerd is, uitgezonderd de groote corra corra van Boane, die van vier Nadjes, en met 60 manschap zal moeten bemand zijn, zoo zullen de volgende Negorijen het nabeschreven getal kruys Orembayen moeten leveren, te weten:

\section{Het Eiland Boano enz.}

Een groote corra corra als gezegd, welke lang moet zijn 90 voeten en breed naar proportie.

Voorts aan kruys Orembayen van de Districten en Negorijen onmiddelijk onder het Hoofdkasteel Amboina als

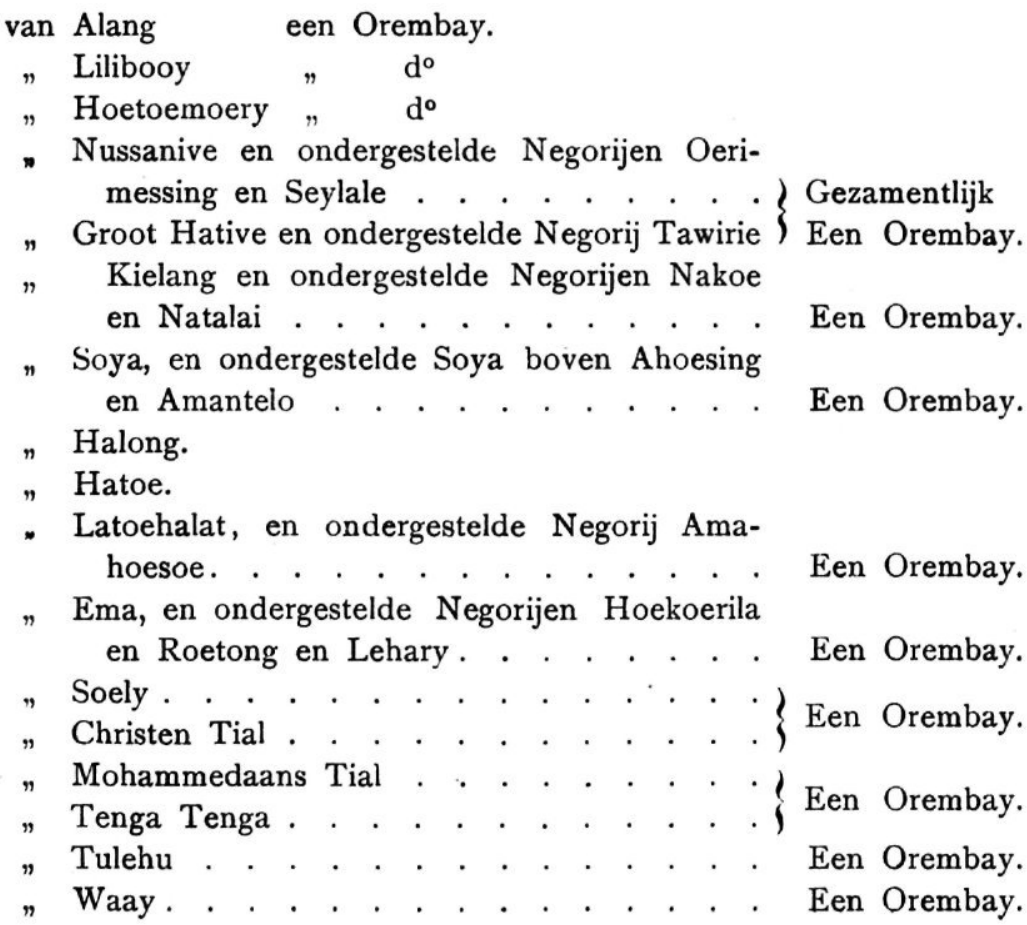


Onder het Resort van Larike.

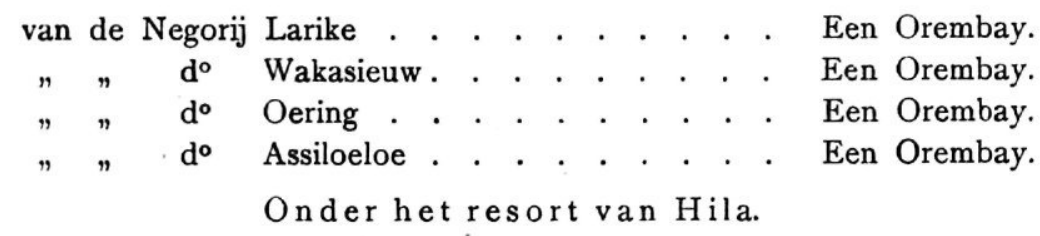

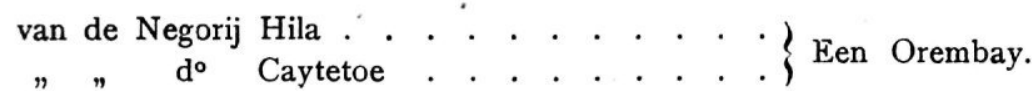

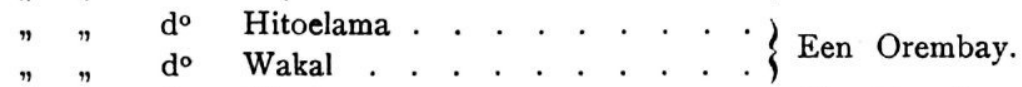

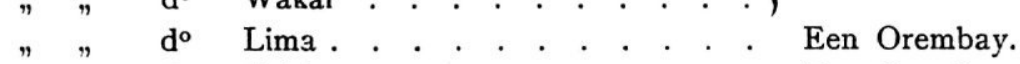
$" \quad$ do Ceith . . . . . . , . . . . Een Orembay.
$" \quad$ do Mamala, en ondergestelde Morila Een Orembay.
$"$ " do Liang. . . . . . . . . . Een Orembay.

Onder het Resort van Haroekoe.

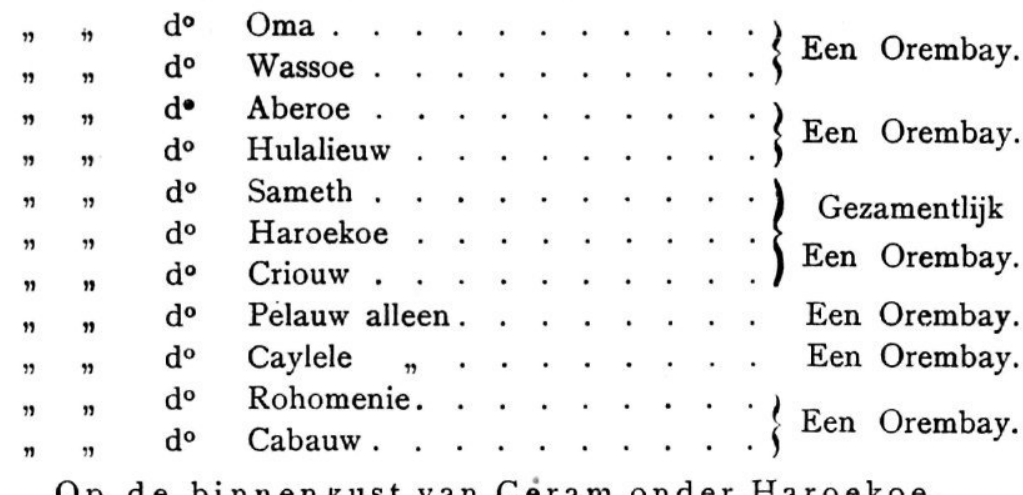

Op de binnenkust van Céram onder Haroekoe.

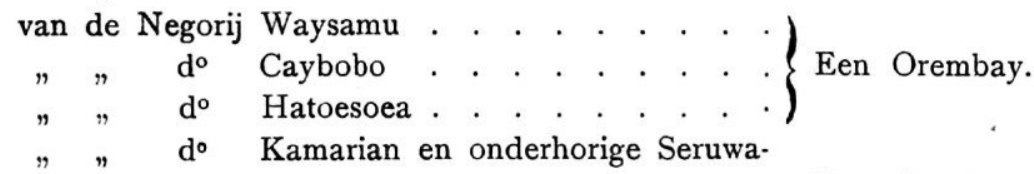

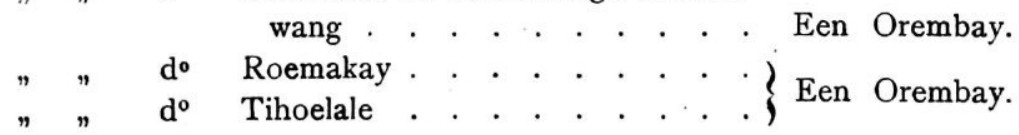

Onder het Resort van de Residentie Saparoea.

Op het Eiland Honimoea.

van de Negorij Siry Sorry . . . . . . . . Een Orembay.

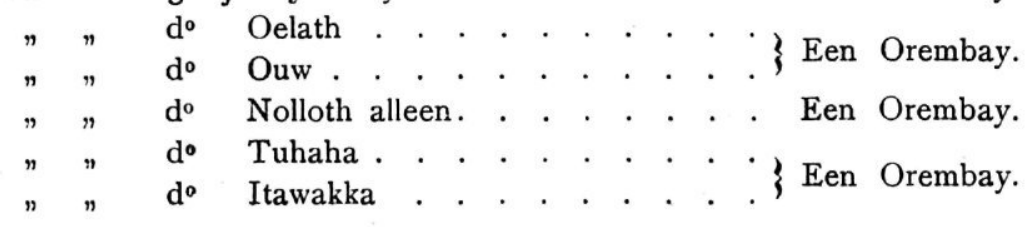




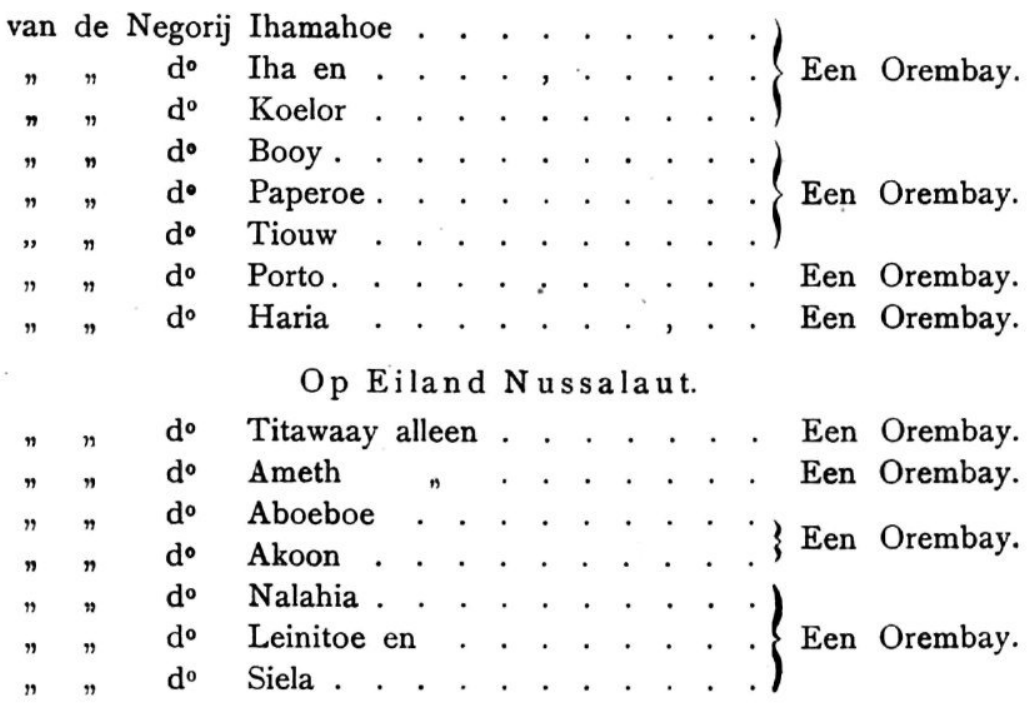

Op de kust van Ceram onder Saparoea.

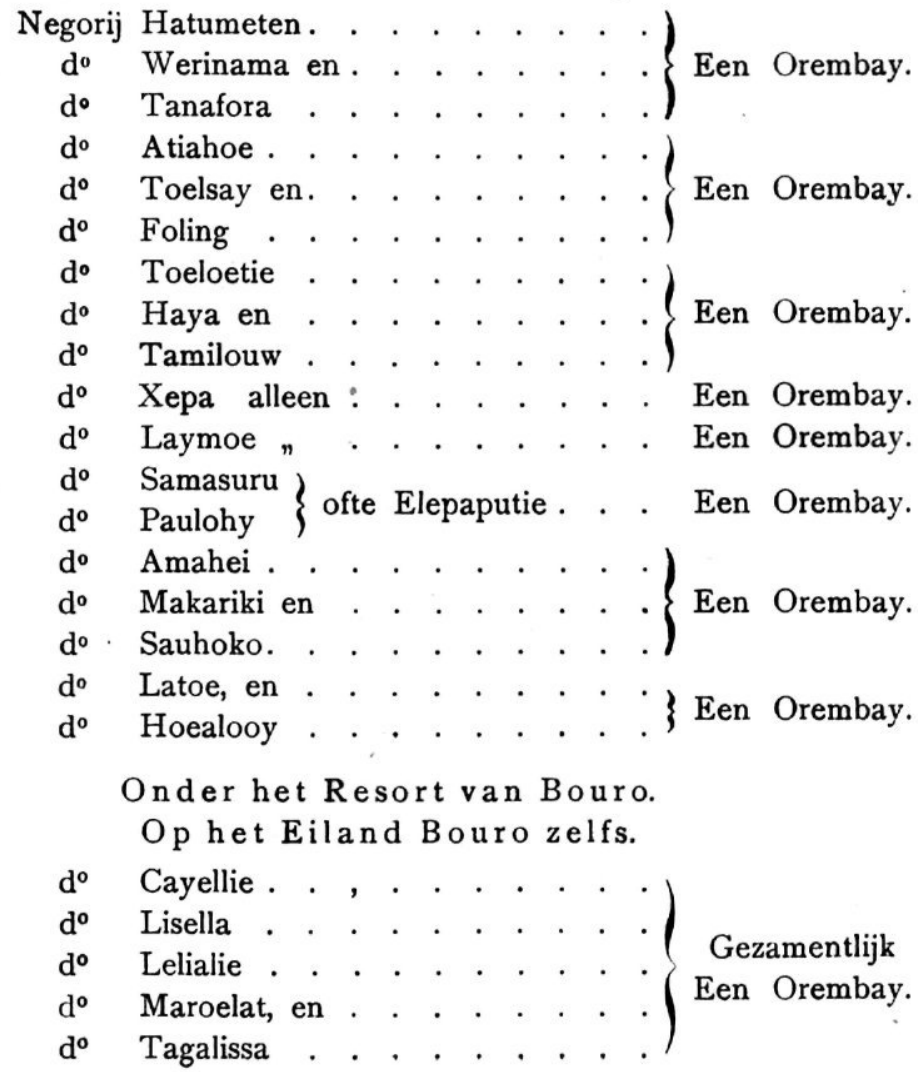




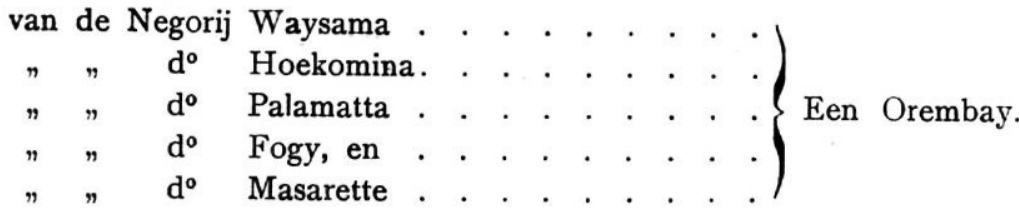

$$
\begin{aligned}
& \text { Op het eiland Amblauw. }
\end{aligned}
$$

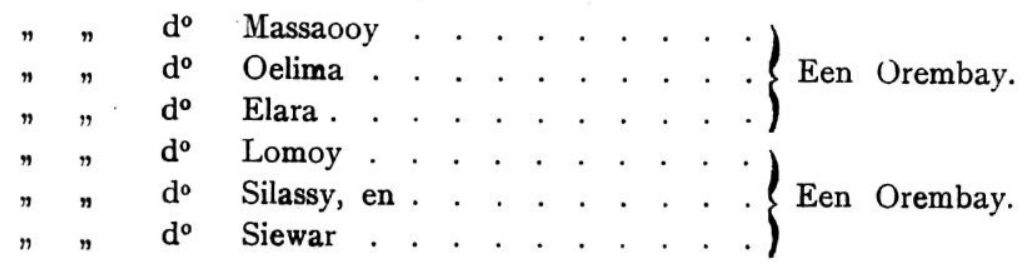

Onder het Resort van Manipa.

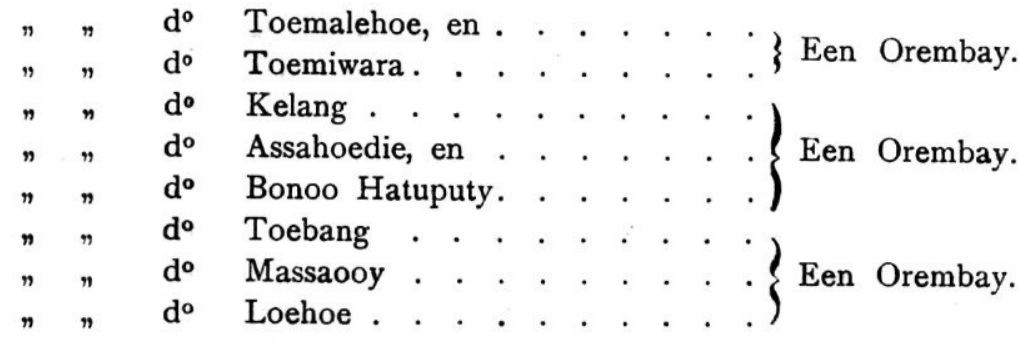

Onder het Resort van $\mathrm{Z}$ away.

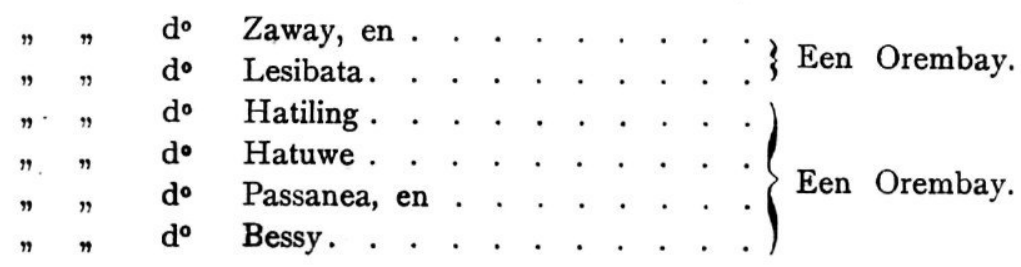

Te zamen 60 Orembayen.

Welke Hongy Orembayen behoorlijk van seyl en treil moeten voorzien en bemand zijn met 36 koppen zonder daar voor iets te genieten, uitgezondert de Regenten die als hoofden op elk dier vaartuigen de Hongie togt zullen bijwoonen te weten voor de gansche togt.

Aan elk Christen Hoofd.

80 ponden rijst.

12 kannen arak en

12 ponden zout spek en vleesch. 
Aan elk Mohamedaans Hoofd.

80 ponden rijst.

12 kannen arak, en

$f 4$ Indische guldens contant instede van het gezouten vleesch.

Moetende voorsch: Orembayen hebben de lengte van 50 a 55 voeten, tegens eene breedte van 12 a 14 voeten en behoorlijk van polders voor draeybassen voorzien zijn.

\section{ART. 17.}

In het doen der Hongy moeten de Inlandsche Hoofden zich stiptelijk gedragen aan den inhoud van het Hongy reglement daartoe telkens door den Gouverneur te beramen het welk hun, tegen dat de Hongy vloot zal vertrekken in de Malleidsche taal zal worden voorgelezen op poene voor de overtreders van te vervallen in de boetens of poenaliteiten daar by gestatueerd.

ART. 18.

De Radjas, Pattye en Orangkayen die nieuwe kruys Orembayen moeten maken zullen in zoo verre dezelve onmiddelijk onder het Hoofdkasteel gehoren, den Gouverneur en die onder de Subalterne Residentien sorteeren de Residenten daar van kennisse moeten geven, om wegens de lengte, breedte en andere vereischten van die vaartuigen orders af te wachten.

\section{ART. 19.}

Die van Roematihga, Mardika, Kleine Hative, Baguala en Laha, worden uithoofde der van jaar tot jaar afnemende bevolking der vier eerstgemelde Negorijen, van het Hongy scheppen geexcuseert, doch zullen daar tegen verplicht zijn de brieven en orders voor het Gouvernement over en weder te bezorgen.

ART. 20.

Alle de Negorijen zoo wel op de Eilanden als op de kust van Ceram moeten steeds hunne kruis Orembayen met het geene daartoe behoord in een goede staat houden teneinde wanneer dezelve door het Gouvernement worden gerekwireerd zonder tijdverzuim daarvan employ gemaakt kan worden. En wanneer het mogt gebeuren dat op de Hongy of enige andere expeditien een kruis Orembay door zeenood, en buiten toedoen of moedwil 
van de opvarenden mogt komen te verongelukken, zal daar voor van wegens het Gouvernement ter gemoet koming van het geleden verlies aan de Negorij betaald worden Een honderd en twintig Indische guldens.

ART. 21.

Het afdoen en beslissen van alle civiele en kleine kwestien onder hunne onderhorigen voorvallende, hetzij nopens de limietscheidingen der doussongs of landerijen, het omvellen van sagoe en het beklimmen van vruchtboomen mitsgaders over het schelden of iets dergelijk op de Subalterne Residentien aan de Residenten overgelaten zijnde, zal zulks ten overstaan der Inlandsche regenten in diens gebied of district het voorvalt nevens nog twee a drie andere op hun volgende en bij de zaak in kwestie geen belang hebbende kapala soas, Orantouas of andere negorijs ingezetenen moeten geschieden, behoudens de vrijheid nog thans dat die genen die zich met de uitspraak mogten bezwaard vinden daarvan kunnen appelleeren aan den raad van Justitie der Moluccos te Amboina. Het beslissen van zodanige zaken zal echter in geenen deel uitgestrekt worden tot crimmineele actien en delicten ofte in het civiele meer dan tachtig Indische guldens waarde bedragen zullende deze voor het gerigte alhier moeten werden gedecideert.

ART. 22.

Bij vacature van Regents posten zullen de genen die daar toe meenen geregtigt te zijn zich kunnen addresseeren, hier onder het Hoofd kasteel onmiddelijk aan den Gouverneur doch op de Subalterne residentien, moetende echter hunne verzoekschriften aan den Gouverneur gerigt zijn, doch de openvallende plaatzen van kapala soas of oudstens in de negorijen kunnen door de Residenten begeeven en vervuld worden mits dezelve steeds zorge dragen dat daar toe geschikte lieden worden aangesteld en dat hun getal niet boven het gewoon gebruik nutteloos vermeerdert worde.

ART. 23.

Bij de Inlandsche Hoofden op Cerams binnen kust onder het resort van Saparoea, Haroekoe en Hila mag zonder last of vergunning van den Gouverneur geen Sanierie of Landvergadering 
gehouden of belegd worden op poene van demissie en verbanning uit de provincie van Amboina.

ART. 24.

De datys der onderscheidene Negorijen zullen altoos op het bepaalde getal gehouden worden, en zal bij het overleiden van een datyhouder onder dit Hoofd kasteel aan den Gouverneur, en op de Subalterne Residentien aan de Residenten daar van moeten worden kennisse gegeven ten einde de plaats van den overledene datyhouder weder ten eersten te vervullen.

ART. 25.

De Inlandsche Hoofden zullen naar uiterste vermogen moeten tegen gaan dat niemand hunner onderhorigen zich voor schuld komen te verpanden of geld op goederen voor hunne lichamen opneemen om daarvoor bij hunne crediteuren dienstbaar te zijn dewijl zulks bij de successive geemaneerde placcaten scherpelijk verboden is en blijft; gelijkerwijze ook het verpanden en veralieneeren van daty, doussongs en plantagien of zogenaamde tatanamangs, het welke voor altoos geinterdiceert blijft.

ART. 26.

Betreffende de Nagel culture en dies leverentie werd de Inlandsche regenten tot een nauwkeurige nakoming voor het toekomende aanbevolen.

A. Dat zij vooral zullen hebben zorge dragen dat de Nagelen tot rijpheid gekomen zijnde ten eersten geplukt worden en niet tot polongs of moernagelen komen te schieten gelijk ook dat de geplukte nagelen niet door kokent water gehaald en dan in de zon of over een klein rokend vuur gedroogt worden, het zij wat oorzaak hun daar toe mogt bewegen. Dewijl de zodanige niet in leverantie acceptabel, maar aan confiscatie onderworpen zullen zijn, maar de rijp geplukte nagelen moeten goed in de zon gedroogd zijn, tot kenmerk van hetwelk zij vol en bruinkleurig zich aan het oog opdoen, z.oodat men dezelve met de nagel door knippen of door het drukken met den vinger breeken kan, ook dat ze rammelen in het overstorten, terwijl dezelve van steelen of stengels gezuiverd en zonder enig mengzel van stoff of vuiligheid moeten zijn. 
B. Dat ingevolge de laatste inrigtingen voortaan in ieder daty onder het onmiddelijk resort van Amboina en op de residentien Hila, Haroekoe en Larike het getal der Nagel boomen bepaald zal blijven op veertig vruchtdragende en vijftig halfwassene en jonge boomen doch op de eilanden Honimoea en Nussalaut voor elke daty op vijf en dertig vruchtdragende en vijftig half wassen en jonge Nagel boomen.

C. Dat indien het Gouvernement een vermeerdering dan wel vermindering in de Nagel culture noodzakelijk mocht oordeelen de daartoe te gevene beveelen stiptelijk zullen worden agtervolgd.

D. Behalven de aanbevolen cultiveering van zekere hoeveelheid Noten boomen onder het onmiddelijk resort van het Hoofdkasteel, op de kust van Leytimor en aan de overzijde der baay, waar van de Noten muscaat en foely aan het Gouvernement tegens betalinge geleverd word, mogen op de andere eilanden, kusten en plaatzen in de provincie Amboina geene Noten muscaat bomen, het zij egte of wilde groeyen of aangekweekt worden dan alleen met speciaal verlof van den Gouverneur in elke Negorij een boom, om te dienen tot huisgebruik van den gene die in zodanige Negorij het gezag voert.

E. Dat Nagel bomen steeds van de zogenaamde talie oetangs, bosch rottings en andere zoorten daar tegens opgroeyende klimop, mitsgaders allerly ruigtens en coescoes gezuiverd en schoon gehouden worden, om eensdeels te beletten dat de specery boomen daar door niet te zeer belemmerd of zelf verstikt worden, en anderdeels omdat de gevolgen hebben doen zien dat deze ruigtens meer dan eens door een onvoorzigtig of ongelukkig toeval vuur gevat hebbende de nabijstaande nagel bomen daar door mede zijn verbrand geraakt.

F. Tot voorkoming zoo veel mogelijk van diergelijke ongelukken blijft een ieder onder zijn district aanbevolen de nodige zorge te dragen op het rondzwerven savonds of snagts op het land met brandende kunnings, lobee lobees of damers en het onvoorzigtig weg werpen derzelve in het bosch, zo mede het opzettelijk in brandsteeken van de coescoes of het lange gras, zullende de zodanige die zich hier aan schuldig maken voor de gevolgen aansprakelijk zijn en naar bevind van zaken gecorrigeerd worden. 
G. In de tijd der leverantie van Nagelen zullen dezelve snagts nergens mogen aangebragt noch ook niet over zee in een vaartuig vervoerd mogen worden zonder ligt in het zelve te hebben en zal voorts geen vaartuig een Negorij of bezetting post mogen voorbij varen zonder ligt te branden, zolang als den nagel pluk en leverantie aanhoud.

H. De Inlandsche Hoofden ten eilanden Nussalaut zullen de Nagelen niet willekeurig door hunne Negorijs volkeren naar Saparua mogen laten overbrengen, maar moeten zulks doen met enige vaartuigen te gelijk, onder het oog en opzigt van den regent van wiens Negorij of district dezelve worden geleverd en daar van behoorlijk kennis gegeven aan den Commandant of posthouder van den Redout op Nussalaut, zooals ook geschieden moet op alle andere posten daar Militaire bezitting legd, gelijk als te Poorto en Hatawano op Honimoea, te Pelauw, op Haroekoe en te Negorij Lima en Hitielama op de kust van Hitoe.

I. Voor elke Bhaar Nagelen van 550 ponden Hollandsch gewigt zal aan de leveranciers betaald worden in Indisch geld $f 73.10$, zijnde berekend tegens 4 stuivers het pond en daarenboven nog voor Barat of hassil geld $f 6.20 \mathrm{p}^{\mathrm{r}}$ Bhaar ter verdeeling onder de regenten en mindere hoofden te weten:

3 gedeelte aan de Regenten . . . . . . . . f 4.-

$\frac{3}{10}$ gedeelte aan de gezamentlijke kapalasoas van

elke negorij. . . . . . . . . . . . . . . . , 2.-

$\frac{1}{10}$ gedeelte aan de marinjo's der negorij . . . \$ 0.20

En aan de leveranciers a 4 St. per pond . . , 73.10 Komt te zamen de door het Gouvernement bepaalde , 80.voor de Bhaar Nagelen van 550 ponden.

Doch van de onmiddelijk onder het Hoofd kasteel te Amboina sorterende Negorijen zal twee procento op het Hassil geld gedecorteerd worden ten behoeve van den g'natoedy of het hoofd van Mardyka tot deszelfs middel van bestaan vermits aan hem en zijne onderhorigen geene nagelboomen toebedeeld zijn.

K. Wanneer Moernagelen door het Gouvernement ter leverantie mogten aangevraagd zijn zullen dezelve tegen de halve prijs der garioffel Nagelen aan de leverantiers uitbetaald worden, teweten tegens $f 40$. - (veertig) Indische guldens de Bhaar van 550 ponden met het Hassil geld. 
L. De leverantie van Nagel zal moeten geschieden ter presentie van den Regent der Negorij, welke als Waagmeester daar bij fungeert, en bij indispositie van den zelven of absentie in dienst zal zijn perzoon door twee kapala soas van de Negorij moeten vertegenwoordigt worden, en zal het opschrijven van hunne zijde moeten geschieden door een schrijver door hun zelf daar toe te verkiezen, de welke voor zijne moeyte genieten mag een stuiver op de uitbetaling van elke ropy of Indische gulden, doch niets wanneer het minder dan een ropy bedraagt.

\section{ART. 27.}

De Inlandsche Regenten zullen verplicht zijn voor de kerken, schoolen en schoolmeesters woningen in hunne Negorijen goede zorge te dragen dat dezelve eens geextrueerd zijnde, in een behoorlijke staat onderhouden worden ten kosten der respectieve Negorijs kassen, doch zal bij capitale vernieuwingen van zodanige gebouwen hier op Amboina het nodig verlof van den Gouverneur en op de Subalterne residentien dat van de residenten daar toe moeten verkregen zijn.

ART. 28.

De Inlandsche Regenten zullen ook ten kosten van de Negorijen een ieder in de zijne, van een bekwame wooning moeten voorzien zijn, en dezelve steeds in een goeden staat houden, om bij overleiden, verplaatzing of andere vacatures wederom voor hunne opvolgers te dienen, waarvan bij vernieuwing echter almede kennis gegeven en permissie zal moeten erlangd zijn, te Amboina van den Gouverneur en op de onderhorige Etablissementen van de Residenten.

ART. 29.

Een der voornaamste plichten der Inlandsche regenten is ten striksten te waken tegen allen smokkelhandel en vervreemding der specerijen, het zij door verkoop, verruiling, wegschenking of op hoedanige wijze zulks ook zoude mogen geschieden zoo mede tegens het vervoeren van nagel en noten muscaat plantjes, zullende wanneer zich daar aan direct of indirect schuldig maken naar de bestaande wetten ten strengsten, anderen ten voorbeelde, gestraft worden. 


\section{ART. 30.}

Zij zullen ook voor hunne Negorijen of op enige hunner onderhorige districten dan wel in derzelver inhammen, baayen, krieken en rivieren niet mogen admitteeren enig vaartuig of vaartuigen het zij van de Cerammers, Burgers, Mardijkers, Chineesen of van enige andere Inlanders of vreemdelingen van welke natie die ook zouden mogen zijn, zonder behoorlijk voorzien te zijn van een Passe door de wettige autoriteiten verleend, maar zijn verpligt zodanige vaartuigen aan te houden en op te brengen aan de naast bij gelege post of ter Residentie waar onder zij gehooren, op poene de straffe van bannissement voor de Radjas, Pattys en Orangkaya benevens hunne oudsten of orangtouwahs, mitsgaders verstooting hunner familien uit de successie in het regentschap.

\section{ART. 31.}

Wanneer het gebeurde dat zich onder het resort van deze Provincie enig schip, schepen of mindere vaartuigen van enige vreemde Natie als Engelschen, Franschen, Portugeesen, Spanjaarden of Amerikanen kwamen te vertonen, en onder enig resort of district der Inlandsche Hoofden te ankeren, zullen de regenten achtervolgens den eed van trouwe aan $\mathrm{Zijne}$ Majesteit den Koning der Nederlanden gezwooren, die vreemdelingen moeten afwijzen en hen allen toevoer, handel en correspondentie ontzeggen en dezelve dienvolgens niet aan of op hunne stranden mogen admitteeren.

\section{ART. 32.}

Waarom hun dan ook scherpelijk verboden wordt het af en aan boord vaaren bij zodanige vreemdelingen, zoo wel als zich met dezelve in enigen handel hoegenaamd intelaaten of ook toetestaan dat zulks door iemand hunner onderhorigen geschieden.

ART. 33.

Doch indien zodanige vreemdelingen tegens wil en dank aan land kwamen of enige vijandelijkheden pleegden zullen die Inlandsche Hoofden en de zoodanige hunne onderhorigen, wier getrouwheid en aankleving voor het Nederlandsche Gouvernement in zig hier tegen te stellen het meest en openlijkst kwam te blijk, naar verdiensten daar voor beloond, en in tegen- 
deel de geenen, die daar inne nalatig geweest of om eenige oorzaak zich toegevend betoond hebben, ten, rigoureusten als ontrouwe onderdanen gestraft worden, voornamentlijk de zulke, die zich mogten onderstaan hebben enige specerijen, hoe gering ook, in kwantiteit of enige planten derzelve te verhandelen, te leeveren en af te staan of de plaatzen daar ze gevonden worden aan te wijzen.

ArT. 34.

De Radjas, Pattys en Orangkayen zullen ook zorge moeten dragen dat hunne onderhorige naturille Amboineezen niet naar Batavia of elders buiten het resort der Moluksche bezittingen gaan vaaren, behoudens nogthans de vrijheid aan dezelve van ouds verleend, om met voorkennis van hunne Regenten voor enigen tijd naar deze of gene Negorij, dan wel van hier en de onderscheiden Residentien visaversa te mogen vertrekken of vaaren, ter verrigtinge hunner particuliere affaires, het bezoeken van vrienden of het inkoopen van provisien en andere gerievelijkheden, uitgezonderd in den oogsttijd der nagelen. Wanneer de vaart eenelijk naar Cerams binnen kust is gepermitteerd, ter afhaal van zagoe, mits dat enige vaartuigen te gelijk en onder opzicht van een der Inlandsche Regenten naar derwaerts vertrekken, daar toe behoorlijk van passen voorzien zijnde.

ARr. 35.

De Inlandsche hoofden zijn voorts gehouden alle deserteurs, het zij Europeaanen of inlanders in dienst van het Gouvernement of te van andere vreemde Natien, zo mede gedroste misdadigers en weggeslopen slaven, die zich in de binnen districten onthouden, na te speuren, aan tegeven en te doen opvatten, mitsgaders bij apprehensie aan de daartoe bevoegde Autoriteiten uit en over te leveren en waarvoor dan ook telkens het bepaalde opvatloon zal worden betaald.

ART. 36.

Wanneer in hunne Negorijen zich iemand met Lijzernye of de Lepraziekte mogt besmet vinden moeten zij daar van behoorlijke kennisse geven en niet gedogen dat de zulken het zij uit betrekking of om andere redenen schuyel gehouden worden ten einde op het eiland Molane, het welke tot een verblijf voor zodanige ongelukkigen bestemd is, verzorgd te worden. 
ART. 37.

Tot instandhouding van het Leprosen fonds, word over de onderscheidene districten betaald het navolgend jaarlijks fournisement ingevolge het besluit van den Gouverneur der Moluccos de dato 20 Juny 1818 te weten:

van de Negorijen onmiddelijk onder het Hoofd kasteel Amboina gehorende . . . Vier stuivers van adidem die onder de Residentie Hila . elke daty of Huis$\mathrm{d}^{\circ} \mathrm{d}^{\circ}$ onder Haroekoe. . . . . . . gezien.

$\mathrm{d}^{\circ} \mathrm{d}^{\circ}$ onder Larike.

van de Negorijen op de Honimoea en Maar twee stuivers Nussalaut . . . . . . . . . , . . per daty.

Waar tegen deze beide laatst gemelde onder de verpligting leggen om de woningen voor de Leprosen ten eilande Molane op te richten en steeds te onderhouden; die van de eilanden Boero en Amblauw moeten drie picols gedroogde visch of dinding sjaarlijks leveren, die van de eilanden Manipa en Boeroe mede 3 pic. gedr. visch of dinding 's jaarlijks.

ART. 38.

De Regenten der respictive Negorijen zullen moeten zorge dragen dat hunne Negorijen, woningen, erven en straaten altoos schoon en zuiver gehouden worden en allen stank en vuiligheid daar uit geweerd worden, als mede dat de huizen niet te digt op een gebouwd worden, de straten te eng zijn, tot voorkoming van besmettelijke ziekten, gelijkerwijze het hen dan ook verboden wordt, om hunne dooden binnen de erven of kerken en kerkhoven, dan wel nabij de tempels en woonhuizen der Inlanders in de negorijen te begraven, op poene van eene boete van vijf en twintig Indische gulden ten faveure van het Leprosen fonds, en weder opdelving van een dusdanig begraven lijk. Terwijl in elke Christen of Mohammedaansche negorij eene aparte begraafplaats op enigen afstand van de negorij zal moeten onderhouden worden, voorzien met een behoorlijke omheining of paggers ten einde geen wilde varkens of honden daar binnen komen en de grond door wroeten.

ART. 39.

De Regenten zullen wijders ook zorge dragen dat door de schoolmeesters der Christenen en de Imans of kassisie der 
Mohammedaansche Negorijen, behoorlijke geboorte en sterflijsten worden gehouden navolgens de modellen.

ART. 40.

Het blijft voor altoos verboden opéén gestapelde steene paggers of muren in de Negorijen op de eilanden Honimoea, Nussalaut, Haroekoe en de kust van Hitoe, aan te leggen of optewerpen, hetzij langs de algemeene wegen of voor bijzondere erven en plantagien, maar kunnen dezelve van Gaba Gaba, bamboesen, of levendige heggen worden aangelegd.

\section{ArT. 41.}

Sjaarlijks onder ultimo December moet door de Inlandsche Regenten en de kapala soas behoorlijk rekeningen worden gedaan van de negorijs gelden en effecten naar een formulier in de Maleidsche taal die zij hier op Amboina aan den Gouverneur en op de onderhorige Residentien aan de Residenten zullen hebben aantebieden, en ingevallen dat een regent door afstand, dimotie of overlijden mogt afgaan, moeten zodanige negorijs gelden en goederen bij rekening behoorlijk aan zijn opvolger worden overgegeven waar voor de kapala soas of oudstens gedurende het Interim zullen hebben te zorgen.

ART. 42.

Als een der voornaamste poincten werd het de Inlandsche regenten inzonderheid aanbevolen de meeste zorge te dragen tot het meerdere doen aanplanten en cultiveeren door hunne onderhorigen van allerleij zoorten van veld-, aard- en boomvruchten mitsgaders het aankweeken van pluym- en andere slachtvee, en het bevorderen der visscherij ten einde daar uit bronnen tot een beter bestaan te vinden en over deze eylanden eene gewenschte overvloed der eerste behoeften tot levensonderhoud te verspreiden.

ArT. 43.

De Inlandsche Regenten worden ook op het dringenst aangemaand en des noods gelast het inenten der kinderziekte door middel van de Pokstof voor te staan, en hun onderhorigen aan te prijzen, als wordende hier door de vernieling, welke de natuurlijke kinderziekte zoo dikwerf toebrengt gewis voorgekomen, kunnende 
de inlanders niet genoegzaam beduid worden dat deze heilrijke operatie een der belangrijkste en heilzaamste uitvindingen is, welke zedert lang is gedaan.

\section{ART. 44.}

En wordt als in dit Reglement geinsereerd beschouwd het reglement op den ontvangst, inweeg, betaling en afscheep der Garioffel nagelen, gearresteerd door Zijne Excellentie den Kommissaris Generaal Buyskes den $21^{\text {en }}$ January 1818.

\section{ART. 45.}

Eindelijk worden de gezamentlijke Regenten op het alle nadrukkelijkst gelast en aanbevolen de vorenstaande orders stipt te agtervolgen en door de mindere hoofden, orangtouas en gemeene inlanders onder hunne bevelen staande te doen agtervolgen, zonder daaromtrend eenige oogluiking, het zij uithoofde van verwantschap als andersins te gebruiken.

En zal Extract dezes gegeven worden aan den Hoofdadministrateur.

Accordeert met voorsch. Register.

De Secret ${ }^{\mathrm{s}}$ van het Gouvernement der Molukkos.

J. M. van SChUler.

Van de door Mr. H. A. Idema en den Controleur B.B. H. J. Jansen in het gewestelijk archief te Ambon gevonden oude officieele bescheiden is een lijst opgemaakt, waarvan een exemplaar is aangeboden aan het Algemeen Rijksarchief, het andere berust in de Boekerij van het Instituut te zamen met afschriften van de volgende bescheiden:

I. Reglement op de in- en uitweging, ontvangst en afscheep enz. van ladingen ter hoofdplaats Amboina en andere buitenkantoren (1753).

II. Generaal Reglement en tarief rakende de afschrijvingen wegens spillagiën enz. (zonder jaartal).

III. Bepalingen omtrent het afleggen van den eed door officieren (20 Jan. 1809). 
IV. Besluit van den Gouverneur der Moluksche eilanden ten opzichte kwijtschelding van straf aan den Engelschman Marry (12 April 1817).

V. Id. in zake reparatie der gebouwen van het Militaire Hospitaal te Ambon (13 April 1817).

VI. Id. naar aanleiding van mishandeling eener slavin door de Ghineesche vrouw Oeng Siang Nie (8 Mei 1817).

VII. Id. inzake kerkelijke afkondiging van huwelijken (5 Sept. 1817). VIII. Verzoek van A. Staalberg, gewezen soldaat in dienst der O. I. C. om een "maandelijksch soulagement” (13 Maart 1818).

IX. Advies aan den Gouverneur der Molukken over verkoop van een stuk grond op Soa Ema.

$\mathrm{X}$. Besluit van den Gouverneur der Moluksche eilanden met betrekking op de Leprozen-inrichting op het eiland Molane (20 Juni 1818).

XI. Id. Vaststelling Reglement op de inkomende en uitgaande rechten (20 Juni 1818).

XII. Id. Reglement voor de Scheepvaart in de Moluksche eilanden. XIII. Adres van Ong Jungkie verzoekende vrijlating van twee zijner wegens dietstal veroordeelde slaven (7 Dec. 1818).

XIV. Pachtconditiën van de saguweer te Amboina voor het jaar 1819.

XV. Tractaat van vrede tusschen den Sultan van Ternate en den Sultan van Tidore (zonder jaartal).

XVI. Schrijven van den Resident van Saparoea aan den Gouverneur der Molukken inzake grensscheidingen van sago- en klappertuinen der bevolking (1 Dec. 1818).

XVII. Besluit der verheffing tot „Sultan van Ceram” van Prins Mohamad Asgar Djalolo (25 Jan. 1826).

XVIII. Varia (No. 1-15). 